\title{
標準クリアランス法による高血圧患者 腎機能の臨床的研究
}

\author{
日本医科大学附属内科学教室 (主任 木村栄一教授) \\ 日本医科大学附属第二医院内科教室（指導岩瀬湴諢師） \\ 高鳥格 \\ Itaru Takatori
}

\section{I. 緒言}

高血圧に渻性，神経性，内分泌性，本態性などい ろいろの種類があるが，何れの場合にも緊機能障害を 伴う可能性があり，殊に，留性高血圧に扔いては，留 虚血が血圧上昇の原因とされる。乞の他の高血圧に括 いても, 高血圧の結果として発生せる婜障害は, 再び 高血圧の原因となり，高血圧と腎機能はきわめて密接 な関係を有する。従つて高血圧患者の診療漈して留 機能の状態を把握することは, きわめて重要である。

今日腎機能検査法として最も信頼されているのは婜 クリアランスの測定である。この方法は 1928 年 Van Slyke $^{1)}$ により創始されたが，その後 Smith $^{2)}$ によ 発展せられ, 現在では系球体や尿細管の各機能, 並び に婜全体としての血行動態を, それぞれ個別的に測定 し得るに至つた。

高血圧に招ける留機能を本法により研究せる 報告3 ${ }^{-6)}$ は, 多数みられる。

しかし，その多くは簡易法を用いての検索であり， 批判の余地なしとしない。よつて著者は, 手枝は複雑 であるが，最子正確とされる標準法をあ兄て採用し，

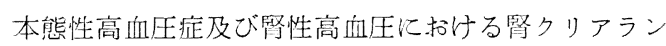
ス値を中心として若干の検索を行つたので, ここに報 告する。

\section{II. 高血圧の腎クリアランス值}

\section{A. 研究目的}

本態性ならびに腎性高血圧症例に括ける婜クリアラ ンス值と各種臨床所見との対比については、すでに㭁 びただしい報告があるが，その大多数はやはり简易法 に上る測定值を用いての観察であり, 標準法を用いた ものは此較的少ない。その意味に扔いて著者はまず, 標準法により測定したクリアランス值と臨床所見との 对比去行った。

\section{B. 対象並ひに研究方法}

日本以科大学第二病院内科の入院及び外来息者を対
象とし, 本熊性高血圧症 103 例及び繁性高血圧 18 例 につき, 各年令層, 各病期にわたり, 腎クリアランス を測定した。

腎クリアランス測定には標準法と簡易法があるが, 本研究に沏いてはすべて標準法を採用した。

患者は前日より一切の投薬を中止し, 当日の朝は絶 食, 約 1 時間の安静後に, 水 $500 \sim 600 \mathrm{cc}$ を飲ませ, 仰阶位に括いて試薬の持続点滴静注を行つた。系球体 滤過量 (以下 GFR と略す) は 100 \% Thio 硫酸 Na により，有効堅血漿流量（以下 RPF と略す）は $10 \%$ p-amino 馬尿酸 Na とより測定した。

Thio 硫酸 Na の定量は Claus Brun 法により, p-amino 馬尿酸 Na は Naphthylethylenediamine 法 (Blatton-Marshall 法)によつた。

約 20 分間飞 2 回の測定を施行し, その平均值を求 めた。粲血流量 (以下 RBF と略す) はへマトクリッ ト值上り, 滤過率 (以下 FF と略す) は GFR RPF より，いずれも計算により求めた。それらの值は，す ベて日本人平均体表面積 $1.48 \mathrm{~m}^{2}$ 亿て補正した。採尿 は全例ともカテーテルにより行つた。

血圧の測定は Riva-Rocci 型血圧計に上り行い，拡 張期血圧は Swann 第 5 点を目標とした。

\section{C. 検查成績}

1. 健常刘照例飞招ける検查成績

晸疾患，心疾思，高血圧の既往歴のない健常男女 10 名を対照に光らび，その測定值を表 1 亿示した：之等 の值は諸家 ${ }^{7,8)}$ の報告とほぼ一致する。

表 1 健常对照こおける留少リアランス值

\begin{tabular}{c|c|c|c|c}
\hline & GFR cc/min & RPF cc/min & RBF cc/min & FF \\
\hline 測定範囲 & 72.0 & 327 & 747 & 0.18 \\
& 141.0 & 7.18 & 1346 & 0.24 \\
\hline 平均 佰 & 104.2 & 492 & 946 & 0.21 \\
標準偏差 & \pm 22.0 & \pm 122 & \pm 119 & \pm 0.04 \\
\hline
\end{tabular}




\section{以下この平均值}

及び標準偏差を正

常範囲として比較

検討を行つた。

2. 高血圧症例

飞抢ける検査成績

検查対象とせる

本態性高血圧症

103 例, 腎性高血

圧 18 例の年令分

布及び性別は表 2
表 2 研究対象例の年令分布

\begin{tabular}{|c|c|c|c|c|}
\hline \multirow{2}{*}{ 年会 } & \multicolumn{2}{|c|}{ 本態性 } & \multirow{2}{*}{$\frac{\text { 腎 }}{\text { 今 }}$} & \multirow{2}{*}{$\frac{\text { 性 }}{\text { 우 }}$} \\
\hline & $\hat{\delta}$ & 우 & & \\
\hline $21 \sim 30$ & 0 & 0 & 1 & 3 \\
\hline $31 \sim 40$ & 3 & 3 & 2 & 3 \\
\hline $41 \sim 50$ & 11 & 15 & 2 & 3 \\
\hline $51 \sim 60$ & 26 & 14 & 1 & 1 \\
\hline $61 \sim 70$ & 16 & 15 & 0 & 2 \\
\hline \multirow{2}{*}{ 計 } & 56 & 47 & 6 & 12 \\
\hline & \multicolumn{2}{|c|}{103} & \multicolumn{2}{|c|}{18} \\
\hline
\end{tabular}

の如くである。

\section{a) 全般的所見}

各症例及び検査成績を一括して表 3 ,表 4 亿示した。 本態性高血圧症例のうち, 正常範囲以下の值を示し たものは, RBF について 85 例 (82.5\%), GFR に ついて 39 例 $(37.9 \%$ )であつた。このことは, 本態 性高血圧症に打いては, 留血流量の低下の制合に糸球 体濾過值は正常に保たれている事を示す。従つて, FF は上昇を示す例が多かつた。

これに対し，腎性高血圧に括いては，RBFは16例 $(88.9 \%), \mathrm{GFR}$ は 14 例 $(77.8 \%), \mathrm{FF} 15$ 例

表 3 本態性高血化における腎クリアランス值

\begin{tabular}{|c|c|c|c|c|c|c|c|c|c|c|c|c|c|c|c|c|c|c|c|}
\hline \begin{tabular}{c|c|} 
症性年 \\
\end{tabular} & 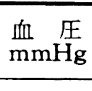 & \begin{tabular}{|c|}
$G F R$ \\
$\mathrm{cc} /$ \\
$\mathrm{min}$
\end{tabular} \mid & $\begin{array}{l}\mathrm{cc} / \\
\mathrm{min}\end{array}$ & $\begin{array}{l}\mathrm{RBF} \\
\mathrm{ccl}\end{array}$ & $\mathrm{FF}$ & 睍 & 量 & $\begin{array}{l}\text { S.C.G } \\
\text { ST.T } \\
\text { 界常 }\end{array}$ & $\begin{array}{l}\text { PSP } \\
15 \text { 分 } \\
\text { 俌 } \%\end{array}$ & 症珄 & $\underset{\mathrm{mmHg}}{\mathrm{m}}$ & $\begin{array}{c}\mathrm{cc} / \\
\min \end{array}$ & $\begin{array}{l}\mathrm{RPF} \\
\mathrm{cc} / \\
\mathrm{min}\end{array}$ & $\begin{array}{l}\mathrm{RBF} \\
\mathrm{ccl} \\
\mathrm{n} \quad \mathrm{min}\end{array}$ & $\mathrm{FF}$ & 1 & 蛋 & $\begin{array}{l}\text { E.C.G } \\
\text { ST.T } \\
\text { 界常 }\end{array}$ & $\begin{array}{l}15 \text { 分 } \\
\text { 値\% }\end{array}$ \\
\hline $1 \% 69$ & 90 & 140 & 425 & & 3 & 3 III & $(-)$ & $+)$ & 15 & $\delta: 50 \mid$ & $/ 106$ & 89.2 & 228 & 506 & 0.39 & $9 \mathrm{~N}$ & $(-)$ & $(+)$ & 25 \\
\hline 2 ช 53 & / 96 & 52.4 & 226 & & .23 & $\mathrm{~N}$ & $(+)$ & & & 우 64 & 60 & 98.2 & 289 & 535 & 0.33 & 3 III & $(+)$ & & \\
\hline 3 ㅇ 44 & / 96 & 121.5 & 432 & 704 & 28 & $\mathrm{~N}$ & $(-)$ & & & 6 & 184 & 97.8 & 392 & 709 & 0.24 & $4 \mathrm{~N}$ & $(+)$ & $(+)$ & \\
\hline 4948 & $/ 100$ & 133.9 & 251 & 472 & .53 & II & $(-)$ & & & 今, 58 & 195 & 83.0 & 309 & 592 & 0.26 & $6 I$ & $(-)$ & & \\
\hline-1 & $/ 110$ & 66.7 & 180 & 361 & 10.37 & I & $(+)$ & $(+)$ & & 851 & 100 & 102.7 & 441 & 882 & 0.23 & $3 \mathrm{~N}$ & $(-)$ & $(+)$ & \\
\hline 6969 & $/ 86$ & 102.8 & 296 & 509 & 34 & II & $(+)$ & $(+)$ & 15 & उ 50 & 100 & 83.3 & 299 & 663 & 0.27 & $7 \mathrm{~N}$ & $(-)$ & $(+)$ & 25 \\
\hline 7 운 & 98 & 73.5 & 344 & 554 & 40.21 & III & $(+)$ & $(+)$ & & $\begin{array}{lll}8 & 45\end{array}$ & 186 & 64.6 & 549 & 1070 & 0.11 & $1 \mathrm{~N}$ & $(-)$ & & \\
\hline 8 우 & $200 / 88$ & 114.0 & 295 & 517 & 70.38 & $\mathrm{~N}$ & $(-)$ & & & $45 \div 56$ & 186 & 131.7 & 599 & 1031 & 0.22 & $2 \mathrm{~N}$ & $(-)$ & $(+)$ & \\
\hline $9 \circ 61$ & 100 & 90.0 & 443 & 735 & 20 & III & $(-)$ & $(+)$ & 25 & 46 \& 54 & 110 & 113.6 & 380 & 653 & 0.29 & $\mathrm{~N}$ & $(-)$ & $(+)$ & \\
\hline $10 \hat{\delta} 64$ & $186 / 95$ & 84.4 & 330 & 611 & 10.25 & I & $(-)$ & $(+)$ & & $7 \%$ & 118 & 80.7 & 365 & 649 & 0.22 & II & $(-)$ & $(-)$ & \\
\hline 11 o 68 & $/ 100$ & 47.3 & 333 & 543 & 14 & III & $(+)$ & $(+)$ & 25 & 48 우 39 & 100 & 111.6 & 452 & 791 & 0.24 & $\mathrm{~N}$ & -) & & \\
\hline 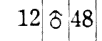 & 96 & 79.9 & 490 & 872 & 20.16 & $6 \mid \mathrm{N}$ & $(-)$ & $(-)$ & & $49 \bigcirc 55$ & & 98.7 & 382 & 679 & 0.26 & $6 \mathrm{~N}$ & $(-)$ & $(+)$ & \\
\hline $13 \widehat{0} 64$ & $180 / 108$ & 124.0 & 328 & 554 & 40.37 & 7 I & $(+)$ & $(+)$ & & 50 ठ $\delta$ : 40 & & 9.5 & 11 & 15 & 0.86 & $6 \mathrm{IV}$ & $(+)$ & $(+)$ & 2. \\
\hline $14 \div 50$ & 110 & 78.9 & 323 & 6 & .24 & IIII & $(+)$ & $(+)$ & & 51 ○ 53 & & 83.8 & 362 & 696 & 0.23 & II & $(-) \mid$ & +1 & \\
\hline $15 \hat{\circ} 52$ & $220 / 126$ & 120.0 & 280 & 571 & 10.43 & I & $(-)$ & $(+)$ & & $52 \hat{b} 33$ & 92 & 92.0 & 426 & 686 & 0.21 & $N$ & $(-)$ & $(-)$ & \\
\hline 16 의 & 1110 & 62.9 & 251 & +24 & 40.25 & I & $(+)$ & $(+)$ & 25 & $3 \div 48$ & 110 & 113.7 & 426 & 732 & 0.26 & $N$ & $(-)$ & $(+)$ & \\
\hline $17 \leqslant 47$ & / 94 & 60.7 & 374 & 778 & 80.16 & 6 I & $(-)$ & $(-)$ & 25 & $54 \widehat{\delta} 63$ & 110 & 75.7 & 318 & 649 & 0.23 & $\mathrm{~N}$ & $(-)$ & $(+)$ & \\
\hline 18 우 63 & $200 / 90$ & 83.1 & 331 & 550 & 0.0 .25 & II & $(-)$ & & & & 110 & $106.1^{\prime}$ & 410 & 669 & 0.25 & II & $(-)$ & $(-)$ & \\
\hline 19 今 63 & 100 & 75.3 & 271 & & & III & $(+)$ & $(+)$ & 15 & 56347 & 00 & 84.1 & 290 & 581 & 0.29 & 9 I & $(-)$ & $(-)$ & \\
\hline 20 万ิ 47 & 90 & 48.6 & 260 & 507 & 70.18 & I & $(-)$ & $(-)$ & 15 & 57 & 90 & 108.9 & 455 & 782 & 0.23 & II & $(-)$ & $(-)$ & \\
\hline 2 & 60 & 82.8 & 456 & $i$ & 18 & $\mathrm{~N}$ & c & ) & 10 & & & 49.5 & 116 & 223 & 0.42 & IV & $(+)$ & $(+)$ & 10 \\
\hline $22 \% 46$ & 100 & 91.0 & 147 & 8 & .20 & II & $(-)$ & $(-)$ & & 59 & & 86.1 & 303 & 487 & 0.28 & $\mathrm{~N}$ & $(t)$ & $(+)$ & \\
\hline 23752 & 110 & 54.9 & 340 & 514 & 40.16 & 5 & $(+)$ & $(-)$ & 3 & & & 86.3 & 221 & 490 & 0.39 & 9. II & +) & $(+)$ & \\
\hline $24 \neq 69$ & 110 & 93.2 & 241 & & 8 & I & $(+)$ & $(+)$ & 18 & 613 & & 80.2 & 477 & 834 & 0.16 & I & $(-)$ & $(-)$ & \\
\hline $25 \div 39$ & 110 & 61.7 & 260 & 419 & 90.23 & I & $(-)$ & $(+)$ & 20 & 0 & 80 & 83.4 & 264 & 487 & 0.31 & $\mathrm{~N}$ & $(-)$ & $(+)$ & \\
\hline 26,652 & 78 & 102.4 & 458 & & 0.22 & $\mathrm{~N}$ & $(-)$ & $(-)$ & & 70 & & 108.2 & 370 & 637 & 0.29 & III & $(-)$ & $(-)$ & \\
\hline $27 \div 69$ & 100 & 109.7 & 356 & 5 & 38 & I & $(+)$ & $(+)$ & 18 & $64 \$ 64$ & 90 & 62.0 & 380 & 729 & 0.16 & i $N$ & $(t)$ & & \\
\hline 358 & / 96 & 50.0 & 236 & & 0.21 & III & $(+)$ & $(-)$ & 20 & 50 & & 117.6 & 356 & 624 & 0.33 & II & $(+)$ & $(+)$ & \\
\hline $298 \quad 44$ & & 69.6 & 230 & & & $\mathrm{~N}$ & $(-)$ & & & $66 \div 60$ & 120 & 101.2 & 335 & 556 & 0.30 & III & $(t)$ & & \\
\hline 30356 & 100 & 119.9 & 464 & 890 & 00.25 & 5 & $(-)$ & $(+)$ & 20 & 6 & & 132.9 & 428 & 778 & 0.31 & $N$ & $(-)$ & $(-)$ & \\
\hline $31 \% 61$ & / 94 & 59.3 & 249 & 47 & .2 & I & $(+)$ & $(+)$ & 15 & & & 113.3 & 448 & 784 & 0.25 & $\mathrm{~N}$ & $(-)$ & $(-)$ & \\
\hline 32 \& 58 & 120 & 87.7 & 191 & & 45 & 5 III & $(+)$ & $(-)$ & & & 110 & 62.9 & 355 & 710 & 0.17 & $\mathrm{~N}$ & $(-)$ & $(-)$ & \\
\hline $33 \div 48$ & 110 & 93.6 & 339 & & 27 & II & $(-)$ & $(+)$ & & 31 & 110 & 140.7 & 480 & 979 & 0.29 & $N$ & $(-)$ & $(-)$ & 20 \\
\hline 851 & $/ 90$ & 69.2 & 309 & & & I & $(-)$ & $(-)$ & & 64 & 86 & 92.7 & 593 & 985 & 0.15 & II & $(-)$ & $(-)$ & \\
\hline 35 우 41 & $162 / 92$ & 110.1 & 308 & 698 & 30.35 & 5 & $(-)$ & & & +68 & $190 / 94$ & 67.2 & 291 & 440 & 0.23 & III & -) & $(+)$ & \\
\hline 36743 & $164 / 94$ & 134.0 & 595 & 099 & 90.22 & $\mathrm{~N}$ & $(-)$ & $(-)$ & & $73 \delta 65$ & $212 / 80$ & 100.5 & 233 & 380 & 0.13 & II & $(+)$ & $(+)$ & \\
\hline $37,5,56$ & $164 / 94$ & 104.0 & 297 & & & I & $(-)$ & $(+)$ & 35 & $74+69$ & 82 & 53.3 & 291 & 517 & 0.18 & I & $(-)$ & $(-)$ & \\
\hline
\end{tabular}


$75 \mid$\begin{tabular}{l|l|l|l|l|}
\hline 58 & $210 / 110$ & 112.7 & 356
\end{tabular} \begin{tabular}{lll|l|l|l}
76 & o 54 & $180 / 90$ & 68.9 & 253
\end{tabular} \begin{tabular}{l|l|l|l|l|l|l}
77 & \& & 41 & $160 / 90$ & 103.7 & 578 & 1
\end{tabular} \begin{tabular}{ll|l|l|l}
78 o 62 & $194 / 110$ & 61.0 & 260
\end{tabular} \begin{tabular}{ll|l|l|l}
79 & \& 51 & $200 / 120$ & 55.3 & 243
\end{tabular} 80 \& 48 180/ 94 81 ร $63 \quad 180 / 92$ 82 ิิ $55 \quad 190 / 110$ 83 ㅇ $60200 / 90$ 84 今 $53 \quad 180$ / 60

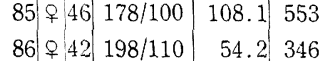
\begin{tabular}{ll|l|l|l|}
87 ㅇ 61 & $190 / 110$ & 105.1 & 326
\end{tabular} \begin{tabular}{ll|l|l|l|}
88 & 952 & $180 / 100$ & 105.9 & 492
\end{tabular} \begin{tabular}{l|l|l|l|l|l|l|l|}
89 & 5 & 53 & $190 / 110$ & 47.5 & 213 \\
\hline
\end{tabular}

\begin{tabular}{ll|l}
76.3 & 296
\end{tabular} 81.4420 66.7306 69. 308
$668|0.31|$ II $|(-)|(+) \mid$ 5630.27 II $(+) \quad(+)$ $1,2540.18 \mathrm{~N}(-) \quad(-)$ 5200.20 I $(+) \quad(-)$ 3910.22 III (t) (t) $91.7563 \quad 1,0010.16 \mathrm{~N}(-) \quad(-)$ 5010.25 I $(+)$ $8750.19 \mathrm{~N}(-) \quad(-)$ 5080.21 I $(-) \quad(-)$ $5210.21 \mathrm{~N}(-)$ $1,0240.19 \mathrm{~N}(-)$ $5220.12 \mathrm{~N}(+)$ $5510.32 \mathrm{~N}(-) \quad(+)$ $8600.21 \mathrm{~N}(-) \quad(-)$ 3720.22 II (t) (t)
|| $90|\hat{\delta}| 68|194 / 100| 124.7|448| 860$ $0.27|\mathrm{~N}|(-) \quad(-)$

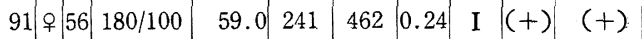
\begin{tabular}{ll|l|l|l|l|l|l|l|l}
92 & 9 & 41 & $162 / 92$ & 113.5 & 297 & 674 & 0.38 & $\mathrm{~N}$ & $(-)$
\end{tabular} $\begin{array}{lllllllllllll}93 & \text { + } & 56 & 170 / 92 & 118.9 & 492 & 891 & 0.24 & \mathrm{~N} & (-) & (-)\end{array}$ $\begin{array}{lllllllllllll}94 & \delta & 58 & 160 / 64 & 85.4 & 271 & 520 & 0.31 & \mathrm{I} & (+) & (+)\end{array}$ \begin{tabular}{l|l|l|l|l|l|l|l|l|l|l}
95 & \multirow{\partial}{0}{} & 51 & $174 / 100$ & 96.1 & 429 & 859 & 0.22 & $\mathrm{~N}$ & $(-)$ & $(-)$
\end{tabular}

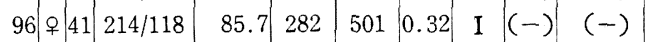
\begin{tabular}{llll|l|l|l|l|l|l|l}
97 & o 63 & $198 / 110$ & 66.2 & 239 & 488 & 0.27 & II & $(+)$ & $(+)$
\end{tabular} \begin{tabular}{ll|l|l|l|l|l|l|l|l}
98 & ㅇ & 41 & $194 / 110$ & 96.7 & 392 & 639 & 0.24 & $\mathrm{~N}$ & $(-)$
\end{tabular} $\begin{array}{lllllllllll}99 & 9 & 55 & 194 / 140 & 44.2 & 108 & 208 & 0.40 & \text { III } & (+)\end{array}$ \begin{tabular}{lll|l|l|l|l|l|l|l|l|}
100 & 9 & 70 & $204 / 80$ & 89.3 & 403 & 745 & 0.22 & I & $(-)$ & $(-)$
\end{tabular} \begin{tabular}{lll|l|l|l|l|l|l|l|l|l}
101 & 5 & 57 & $184 / 100$ & 114.2 & 402 & 728 & 0.28 & $\mathrm{~N}$ & $(-)$ & $(-)$
\end{tabular} $\begin{array}{llllllllllll}102 & \text { o } & 65 & 214 / 80 & 124.5 & 314 & 511 & 0.39 & \text { II } & (+)\end{array}$

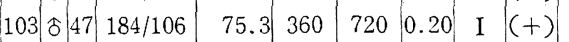

表 4 腎性高血圧における腎少アランス值

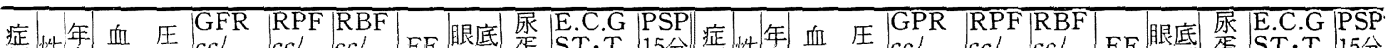

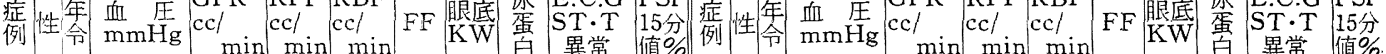

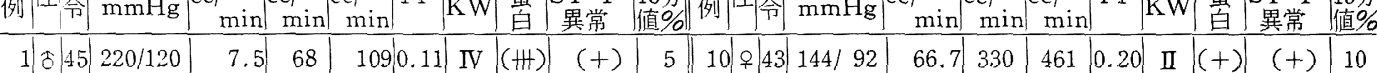

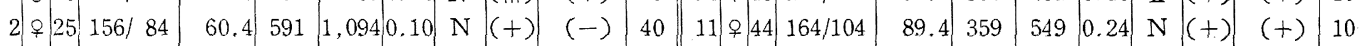

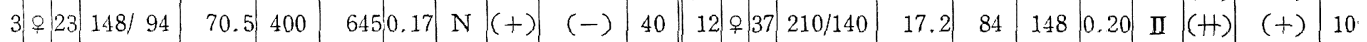

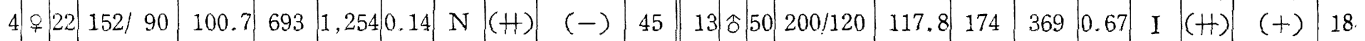

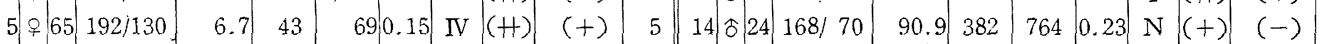

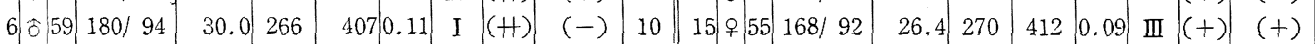

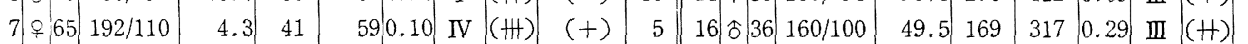

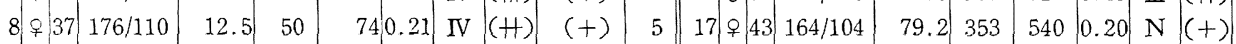

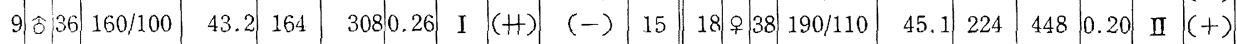

(83.3\%) が，正常範囲以下の值者示した。症例 13 の 如く, FF の高度上昇を示した1例もあつたが，一般 核高压に标いては, RBF, GFR, FFいずれも減少 傾向を呈した。

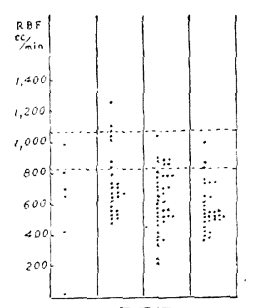

a. $\mathrm{RBF}$

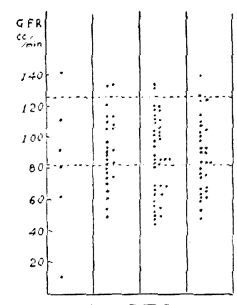

b. GFR

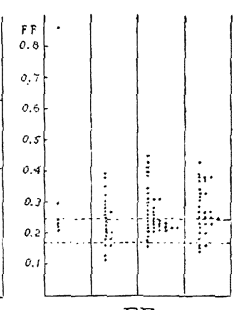

c. FF
図 1 本態性高血在に抄け节腎クリアランス值の年令別観察

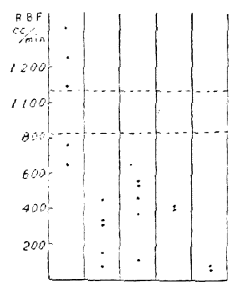

a. RBF

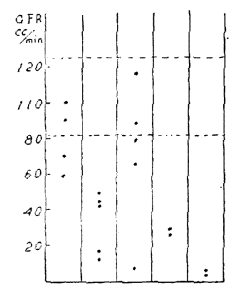

b. GFR

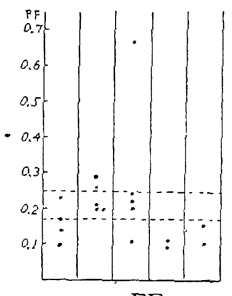

c. FF
困 2 腎性高血生における腎クリアランス值の年令別推察 b）年令と腎クリアランス

本態性高血圧症江打ける各測定值を年令別汇観察し た成績を図 I a , b , c 飞示す。

RBF 飞関しては，40才以上では年令と共に減少す る傾向が，有意の差をもつて認められた。31〜40才 に捈ける RBF 值は，40才以上より小なる如くみ られるが，これとは RBF の高度減少を示す悪性高 血圧の 1 例が含まれていることも関係している。こ れを除外すれば，31〜40才と 41〜50才の間には， 推計学上有意の差を認めることができなかつた。

図1 b は年令別にみた GFR を示すが, 推計学的 に年令による差を認めず，FF では図 1c 亿示す如 く, 悪性高血圧症の1例を除外するときは, 31〜 40 才と 41〜50才の間には差がなく，51〜60才，61〜 70 才では上昇を示した。

即ち本態性高血圧症飞扬いては 51 才以后になる と, GFR にはそれ程の变化がなく, 主として RBF の減少がみられた。従つて FF は上昇した。

筱性高血圧江执いては, 図 $2 \mathrm{a}, \mathrm{b}, \mathrm{c}$ の如く, 20 才台を除き， 31 才以上では RBF! !著明な減少が みられた。これに対し，GFR の変化には，年令と 
の関係が著明でなかつた。FF は 21〜30才では 31〜 40 才より低值を示し，41 才以上になるとまた渐次減 少傾向を示した。21〜30才に批ける低值の理由は, 急 性简炎例が含まれているためと解される。

c) 血圧と RBF

本態性高血圧症に捺いては, 図3 亿示す如く, 収縮 期血圧值と RBF の值の間には，1％以下の危険率老 もつて有意の逆相関が証明された。収縮期血圧 200 $\mathrm{mmHg}$ 以上の例は, 殆んどすべて $(95.8 \%)$ が 700 $\mathrm{cc} / \mathrm{min}$ 以下の $\mathrm{RBF}$ を示した。しかし, 収縮期血圧 $200 \mathrm{mmHg}$ 以下でも，RBF の低值を示すものが相当 あつた。

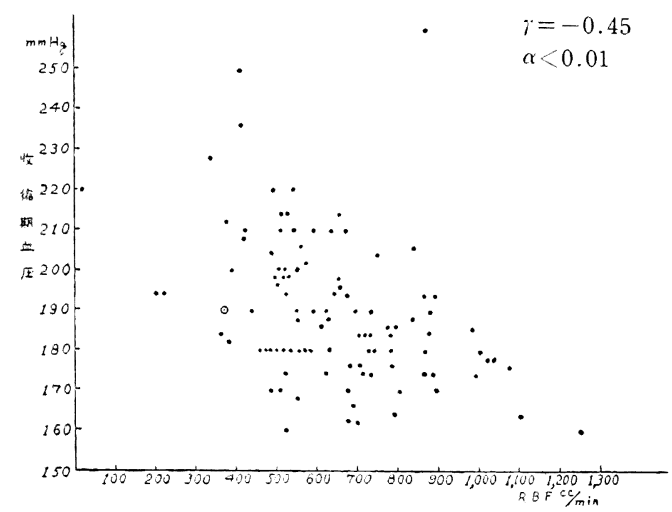

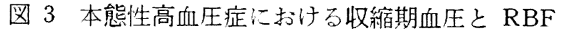

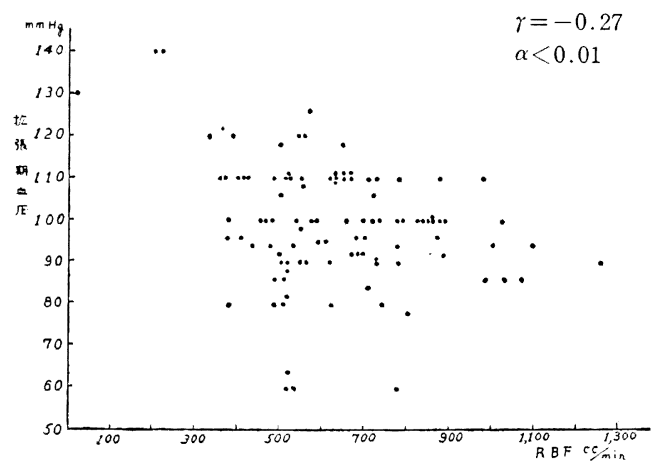

図 4 本態性高血圧症における拡張期血圧と RBF

抬張期血圧と RBF の間飞も，図4 亿示寸如く有意 の逆相関がみられ，抬張期血圧 $110 \mathrm{mmHg}$ 以上では 殆んど全例飞減少を認めた。しかし，110 $\mathrm{mmHg}$ 以 下にても $500 \mathrm{cc} / \mathrm{min}$ 前後の $\mathrm{RBF}$ 值を示すものが相 当あつた。

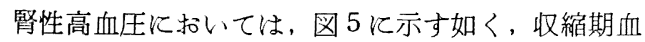
圧と $\mathrm{RBF}$ との間には逆相関がみられたが，搪張期血 圧との間の逆相関は有意でなかつた。
(1867) $-63-$

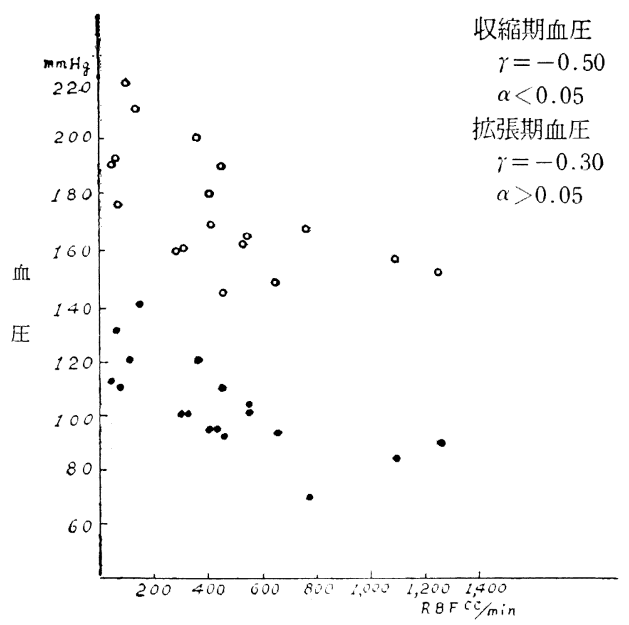

图 5 婜性高血圧における収縮期拡張期血压と RBF

。収縮期血圧

- 拡張期血压

d) 血圧と GFR

本態性高血圧症に括ける収縮期血圧と GFR の間に は，図6亿示す如く，一定の関係は見出されず，比較 的広い分布を示し，有意の相関をみなかつた。収縮期 血圧 $200 \mathrm{mmHg}$ 以上を示す 26 例中, GFR 減少例 は9例 $(35 \%)$ であつた。

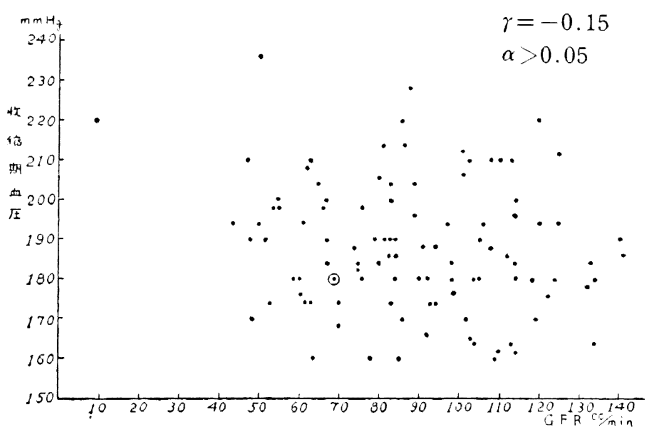

図 6 本態性高血圧症における収維期血圧と GFR

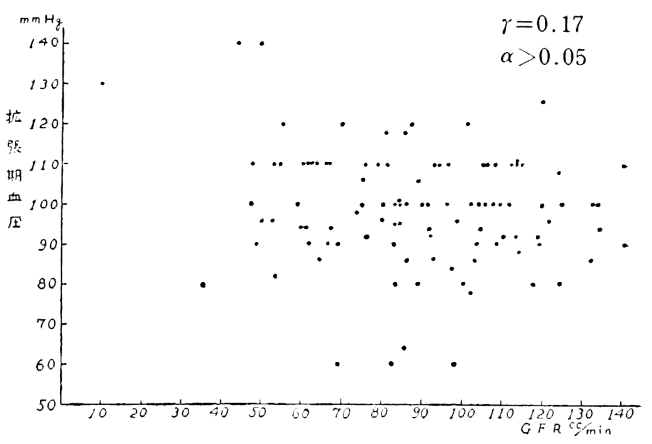

図 7 本態性高血圧における拡張期血圧と GFR 拡張期血圧に打いても図 7 亿示す如く，有意の相関 
$-64-(1868)$

を見出し得なかつた。しかし，収縮期血圧 $200 \mathrm{mmHg}$ ， 拡張期血圧 $130 \mathrm{mmHg}$ を示した恶性高血圧症 1 例は, GFR の極度の減少を示した。

督性高血圧

飞扮计る血圧

と GFR の関

倸は, 図8 K

示す如く, 収

縮期血圧汇つ

いても, 拡張王

期血圧飞つい

ても有意の逆

相関を示し

た。

本態性高血

圧々督性高血

圧の間飞括け

る,かかる差

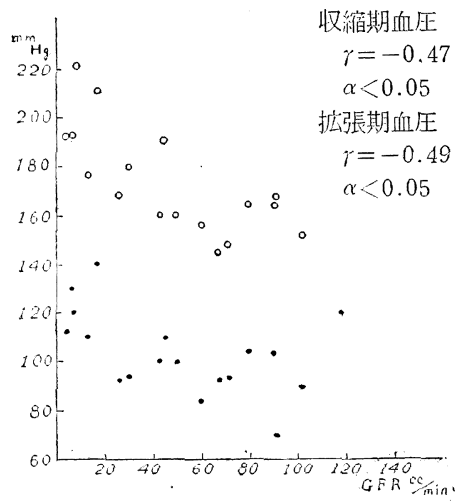

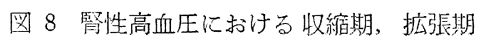
血压と GFR

。収縮期血圧

- 拡張期血圧

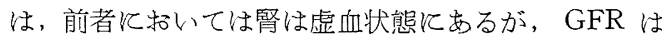
保たれているのに対し, 後者は筒虚血と共飞糸球体の 障害が加わつているためと考光られる。勿論, 本態性 高血圧症でも RBF が著明に減少すると，GFR も強 く減少する傾向が存在した。

e) 血圧と $\mathrm{FF}$

図 9 亿示す如く, 本態性高血圧症に初いては, 収 縮期血圧と $\mathrm{FF}$ との間海有意の正相関がみられ，収 縮期血圧 $210 \mathrm{mmHg}$ 以上示す 16 例中, 13 例飞 FF の上昇がるられた。

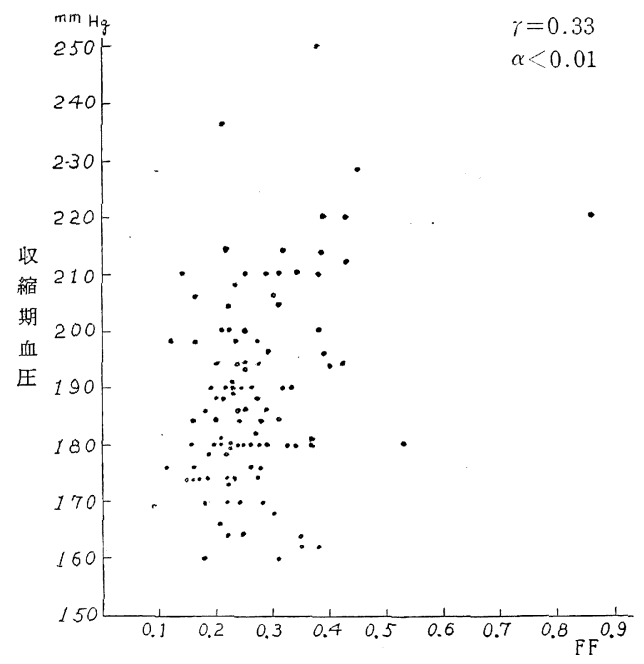

図 9 本態性高血圧症における収縮期血圧と FF
これ《対し，

筱性高血圧症例

そ扮いては, 図

10 亿示す如 $<$,

有意の相関関保

は見られなかつ

た。

f) 眼底所

見と筲クリア

ランス

本態性高血圧 症 103 例の眼底 所見を Keithwagener 往つ て分類し，それ 収縮期血圧 拡張期血圧 $\gamma=0.09 \quad \gamma=0.15$ $\alpha>0.05 \quad \alpha>0.05$

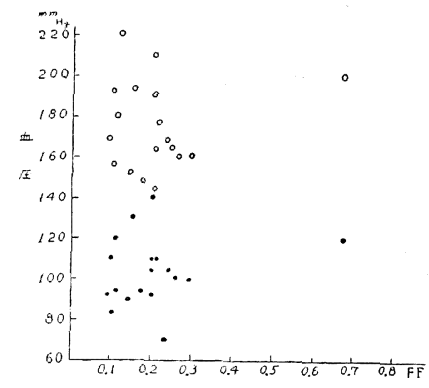

図 10 腎性高血压に㧍ける収縮期, 拡 張期血圧と $\mathrm{FF}$

- 収縮期血王

- 拡張期血圧

と $\mathrm{RBF}, \mathrm{GFR}$ 及び $\mathrm{FF}$ との関係を調べた。その成 績は, 図 $11 \mathrm{a}, \mathrm{b}, \mathrm{c}$ の如くである。即ち, 本態性高 血圧症飞扮いては, 眼底所見の高度になると従い, RBF，GFR は诚少し，FF は上昇する傾向が有意性 をもつて認められた。特に, K-W IV 度群では, RBF, GFR 共治度の減少を示し，FF の高度上昇がるら れた。ただし，眼底所見正常群，並びに K-W I 群汇 ても， RBF のかなり低下せるものがあり，反対に KW II 群以上飞正常值を示す GFR がかなり多い事上
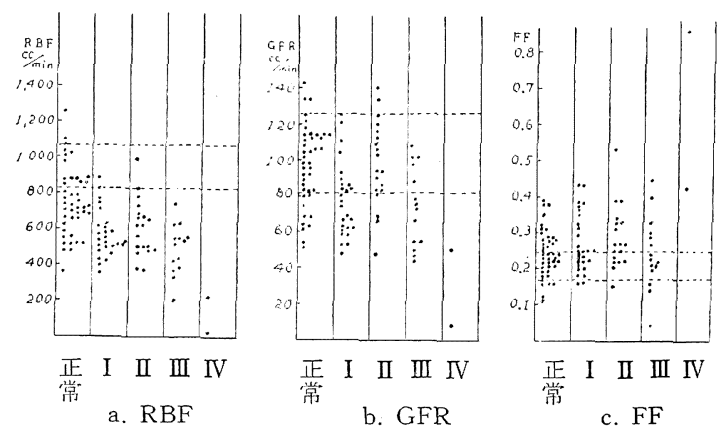

図 11 本態性高血圧症における腎タリフランスと眼底所見

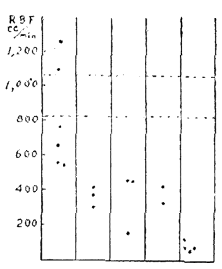

政 I II III IV

a. RBF

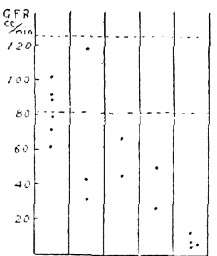

焉 I II III IV

b. GFR

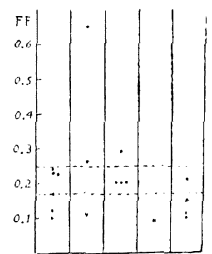

曹 I II III IV

c. $\mathrm{FF}$
図 12 腎性高血圧における婜クリアランスと哏底所見 
りみれば，眼低所見のみより高血圧症の腎機能を推定 することは適当でないといわなければならない。

腎性高血圧症例飞括ける眼底所見之 RBF, GFR, FF との関係は, 図 $12 \mathrm{a}, \mathrm{b}, \mathrm{c}$ の如くで, やはり有 意の差をもつて, 眼底所見の進むにつれ減少傾向がみ られたが，FFには一定の傾向はみられなかつた。た だし，K-WI 群にてFF 0.67 を示す1例があつた。

g）尿蛋白と腎クリアランス

本態性高血圧症につき, Sulfosalicyl 酸法に上る尿 蛋白定性反応の有無と, RBF, GFR, FF との関係走 図13 亿示した。

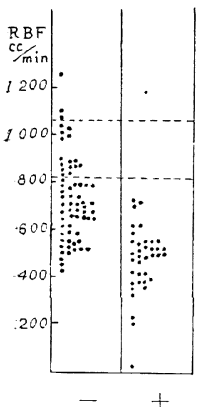

a. $\mathrm{RBF}$

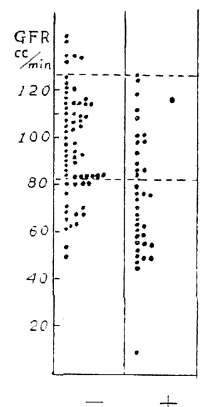

b. GFR

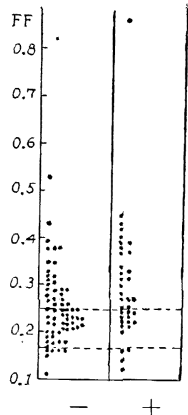

c. FF
図 13 本態性高血圧症に扮ける筒クリアランスと尿蛋白

蛋白尿陽性群は陰性群飞比 乙，RBF，GFR いずれも有意 の差をるつて減少を示した。し かし, FF Kついては推計学的 炕差を認めなかつた。

\section{h) 心電図所見と RBF}

対象とせる症例のうち, 心電 図を撮影しえた本態性高血圧 81 例，䡒性高血圧 15 例飞つき, 心電図所見と RBF との関係を 図 14 亿示した。

心電図上 $\mathrm{ST} \cdot \mathrm{T}$ 亿異常所見 を有したものは，然らざるもの に比し,有意の差をもつて RBF の減少を示した。

i) PSP 15 分值と RBF 本態性高血圧 24 例, 埥性高 血圧 13 例, 計 37 例飞招いて PSP 調べえた。その 15 分值

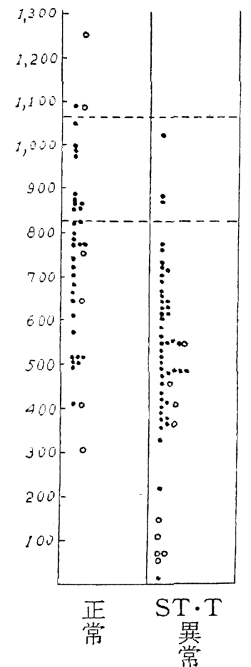

図 14 E.C.G 所見と $\mathrm{RBF}$

。腎 性

・不態性
と RBF との関係を図 15 亿示したが，1\%以下の危 険率にて有意の相関が認められた。

D. 考案
(1869) $-65-$

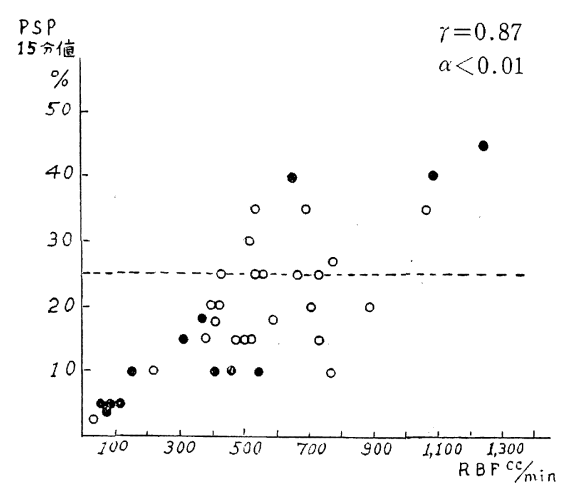

図 15 PSP 值 (15 分) と RBF

。本態性

、腎 性

1）年命と腎クリアランス

Corcoran'》とよれば, 本態性高血圧症の初期には婜 機能は扔かされて斿らず，進行すると RBF も GFR も減少するという。そのいるで著者は, 本症の進行度 の指標の 1 つして年令を選び，これと腎機能検査所 見とを比較した。その成續は図 1，2 亿示す如くで， GFR 値飞年令別に上る差をみなかつたのに対し，

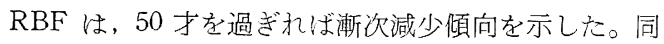
時に FF は上昇索示した。

大島 ${ }^{10}$ は, 本症ではまず $\mathrm{RBF}$ の減少と $\mathrm{FF}$ の上昇 が扰こり, 次いで GFR が減少すると述べているが， 著者の成績は括拈む权一致した。しかし，GFR の著 減をみるに至つたものは少なかつた。

著者の留性高血圧症例でも, やはり RBF の減少傾 向がタられた。GFR 飞関して注年令に上る一定傾向 はみられなかつたが，50才すすぎれば著明な減少を 示した。FF性本態性高血圧症例江打けると反対江,

40 才以上では減少傾向を示した。

FF が21〜30 才に㰨いて，31〜40 才上り低值を示 したのは, 症例のうちに急性简炎を含も故と解され る。急性腎炎江沏いて FF の低下寸ること山, 既に

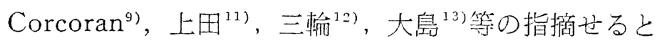
ころだからである。

慢性腎炎末期堅クリアランス値が減少することは Corcoran")の述べているところであり，FF は高低種 々の変動を示すとされ, 上田 ${ }^{11}$, 三輪 ${ }^{12)}$, 大身融等も 慢性腎炎の万ち高血圧を有するもので恃減少を示し， 殊にその未期㵔減を示すといらている。著者の成 績もそれに一致する。

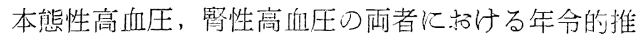
移を比䫒するに，最も著明な差は，FF の態度に差の 
$-66-(1870)$

あつたこと，50 才以上の篎性高血圧に拓ける GFR の堿少が，本態性よりはるかに高度であつたことであ る。

\section{2)焎圧と腎クリアランス}

堀井 ${ }^{14)}$, 高术 ${ }^{4}$, 大島 ${ }^{6)}$, Goldring ${ }^{15)}$ 等(本態性高 血圧症に扮いては，血圧と緊クリアランス值殊飞 RBF が逆相関索示すと報告している。著者の症例に扮いて も收縮期血圧の上昇に伴つて RBF が減少するという 有意の逆相関がるられた。拡張期血圧についても同粎 の逆相関があつた。殊に，収縮期血圧 $200 \mathrm{mmHg}$ 以 上ては殆んどすべての例が RBF の堿少を示し，拡張 期血圧 $120 \mathrm{mmHg}$ 以上では全例に RBF の減少をみ た。しかし，収縮期血圧 $200 \mathrm{mmHg}$ 以下に招いて も， RBF の減少を示すものが相当にみられた事は， 血圧值の夕によつて RBF 在推定することの危険性を 示寸。

一方, 血圧上GFR の間には一定の関係はみられ ず，拡張期血圧についても同様であつた。収縮期血圧 が高くなる程，GFR 減少例が多いという報告 ${ }^{14)}$ も るが，著者の成績はこれを支持しない。

督性高血圧においては，やはり収縮期血圧と RBF の間に有意の逆相関がみられたが，本態性高血圧症に 扣けるとは異なり，GFR との間にも有意の逆相関が みられた。

又拡張期血圧は GFR と有意の逆相関を示したが, $\mathrm{RBF}$ とは有意の逆相関を示さなかつた，

即ち, 本態性高血圧では, 血圧と RBF の間飞相関 が見出されたのに対し，婜性高血圧では，GFR の㾁 うが血圧とより密接な関保を有した。

3）眼底所見と篎クリアランス

本態性高血圧症の眼底所見と腎クリアランス值がほ ぼ平行関係にあることは周知の事奉である(1),6),14)。著 者の成䋶に拈いても， $\mathrm{K}-\mathrm{W}$ 度の進行に伴つて, 腎ク リアランス值が低下するのがみられた。 $\mathrm{K}-\mathrm{W} I$ 度と II度では之れ程の差は見られなかつたが，亚度になる と, RBF, GFR 共に目立つて減少した。しかし, 眼 底所見が正常でも RBF 減少を示すものも多い故, 眼 底所見のみから婜機能障害の程度の推測を行うのに は、充分な注意を要する。

婜性高血圧においても $\mathrm{K}-\mathrm{W}$ 度の進行と共に, RBF, GFR の減少が少られ，FFも低下傾向を示した。

4) 尿蛋白と婜クリアランス

尿蛋白陽性群は, 全例に括いて RBF の減少を示し た。GFRについても, 有意の差をもつて陽性群が減
少を示し，FF の上昇傾向がみられた。これらの成縝 は堀井 ${ }^{14)}$, 大島他 ${ }^{16)}$ の報告とほほ一致した。

5) 心電図と RBF

心電図に ST・T の異常を認めた例では, 正常群に 比し, 有意の差をもつて RBF の減少傾向が認められ た。特に RBF の高度減少例の弓ちには, 正常心電図 を示すものはみられなかつた。然し心電図正常であつ ても, RBF の柽度, 中等度减少を示す例が 39 例中 25 , 例飞恐められたことは，注目に值する。

III. 諸種降圧剤, 殊に Chlorothiazide 系薬削の. 腎機能に及ぼす影響

\section{A. 研究目的}

血圧下降は婜流血量の减少を来たすが，各種降圧剤 の腎流血量飞対する影饗は必らずしも一椂でなく、薬 剤による差がある(17)20)。 $\mathrm{C}_{6}, \mathrm{C}_{5}$ その他の節遮断剤が 婜流血量を堿少せしめる傾向のあること，1-Hydrazinophthalazine はこれ增加せしめること,Veratrum viride 或いは Reserpine ではこれほど著明な影響は ないこと、などはすでに確認されて扣り、ごく最近登 場したChlorothiazide 系楽剤は，留流血量に対する 影響を特に有しないとされている171,21,,22)。

しかし、Chlorothiazide 系薬剤住関する研究の多く は, 数日乃至数週にわたる治療的投与の前后の測定值 を比較して，か〉る結論を下したものである。従つ て，投与直后の腎機能について観察を行う必要がある と考克られるが，急性降圧実験時に打ける研究は主と して動物実験もしくは正常人についてなされ，高血圧 患者について調べた報告は見当らない。

よつて著者は, 各種 Chlorothiazide 系薬剤を静注 し，その直接効果を観察すると共に，他剤と併用した 場合について子検索を行つた。

\section{B. 研究方法及ひ対象}

前節に述べた研究方法に從い, 各クリアランス值を 測定したほか, 次に述べる諸值についても測定乃至計 算を行つた。 $\mathrm{Na}, \mathrm{K}$ の測定は日立製 EPU 2 型焰光、 分光光度計 $\mathrm{H}-2$ 型焰光装置によつた。

腎血管抵抗值 $\mathrm{RVR}=\frac{\mathrm{MBP}}{\mathrm{RBF}} \times 10^{3}$

細尿管水分再吸収率 $T R R=\frac{G F R-V}{G F R} \times 100 \%$

$\mathrm{Na}$ クリアランス $\quad \mathrm{C}_{\mathrm{Na}}=\frac{\mathrm{U}_{\mathrm{Na}} \times \mathrm{V}}{\mathrm{P}_{\mathrm{Na}}}(\mathrm{cc} / \mathrm{min})$

Kクリアランス $\quad \mathrm{C}_{\mathrm{K}}=\frac{\mathrm{U}_{\mathrm{K}} \times \mathrm{V}}{\mathrm{P}_{\mathrm{K}}}(\mathrm{cc} / \mathrm{min})$

$\mathrm{Na}$ 再吸収率 $\mathrm{R}_{\mathrm{Na}}=\left(1-\frac{\mathrm{U}_{\mathrm{Na}} \times \mathrm{V}}{\mathrm{P}_{\mathrm{Na}} \times \mathrm{GFR}}\right) \times 100 \%$. 
K再财収率 $\mathrm{R}_{\mathrm{K}}=\left(1-\frac{\mathrm{U}_{\mathrm{K}} \times \mathrm{V}}{\mathrm{P}_{\mathrm{K}} \times \mathrm{GFR}}\right) 100 \%$ なお，

$\mathrm{V} \cdots \cdots \cdots 1$ 分間尿量 $(\mathrm{cc} / \mathrm{min})$

$\mathrm{MBP}$ …平均血圧(最小血圧 $+\frac{\text { 脈圧 }}{3}$ )

$\mathrm{P}_{\mathrm{Na}} \cdots \cdots$ 血清 $\mathrm{Na}$ 濃度 $(\mathrm{mEq} / l)$

$\mathrm{P}_{\mathrm{K}} \cdots \cdots$ 血清 $\mathrm{K}$ 濃度 $(\mathrm{mEq} / \mathrm{l})$

$\mathrm{U}_{\mathrm{Na}} \cdots$ 尿中 $\mathrm{Na}$ 濃度 $(\mathrm{mEq} / \mathrm{l})$

$\mathrm{U}_{\mathrm{K}} \cdots \cdots$ 尿中 $\mathrm{K}$ 滶度 $(\mathrm{mEq} / l)$

である。

まず降圧凮投与前のクリアランス值を測定したの ち，降圧剤を投与し，約 5 分括きに血圧を測定しつ 〉, 明瞭な血圧下降を生じた時間に，再びクリアラン スの測定を行つた。2 回にわたり測定せる例もあつ た。ただし，Chlorothazide 系楽剤投与后には，直后 より尿量増加をみることがあるので，クリアランスの 測定も直后より開始した。詳細については表 6〜12 参照されたい。

使用薬剤, 対象症例数, 投与量, 投与経路を表 5 K
示す。患者の年令は 24才〜70 才であつた。

表 5 使用薬剂, 対象例数, 使用量, 使用法

\begin{tabular}{|c|c|c|c|}
\hline 使用薬剂名 & $\begin{array}{l}\text { 本態性 } \\
\text { 高监生 }\end{array}$ & $\begin{array}{l}\text { 监性 } \\
\text { 高血厘 }\end{array}$ & 使用量, 使用法 \\
\hline $\mathrm{R}_{\mathrm{S}}$ & 3 & 2 & $0.8 \sim 1.0 \mathrm{mg}$ 静脈内 \\
\hline $\mathrm{Hy}$ & 2 & 1 & $20 \mathrm{mg}$ 静脈内 \\
\hline $\mathrm{C}_{\mathrm{b}}$ & 5 & 0 & $25 \sim 35 \mathrm{mg}$ 筋肉内 \\
\hline $\mathrm{CT}$ & 4 & 0 & $500 \mathrm{mg}$ 静脈内 \\
\hline HCT & 1 & 1 & $50 \mathrm{mg}$ 静脈内 \\
\hline $\mathrm{CT}+\mathrm{R}_{\mathrm{S}}$ & 3 & 0 & $500 \mathrm{mg}+1.0 \mathrm{mg}$ 静脈内 \\
\hline $\mathrm{HCT}+\mathrm{C}_{6}$ & 3 & 0 & $\begin{array}{l}50 \mathrm{mg} \text { 静脈内 }+25 \mathrm{mg} \text { 筋 } \\
\text { 肉内 }\end{array}$ \\
\hline 計 & 21 & 4 & \\
\hline
\end{tabular}

$\mathrm{R}_{\mathrm{S}}$ : Reserpine : Apoplon (第一製薬)

Hy : 1-Hydrazinophthalazine: Apresoline (Ciba)

$\mathrm{C}_{6}$ : Hexamethonium: Methobromin (山之内)

CT : Chlorothiazide: Chlotride (Merck)

HCT : Hydrochlorothiazide : Dichlotride (Merck)

\section{C. 検 査 成 績}

1) Reserpine

表 6 亿示した如く，全例において収縮期血圧 24〜 $34 \mathrm{mmHg}$ の下降学認めた。昖張期血圧の下降は 4〜 表 6 Reserpine (Apoplon) 静注前㣪の留機能所見

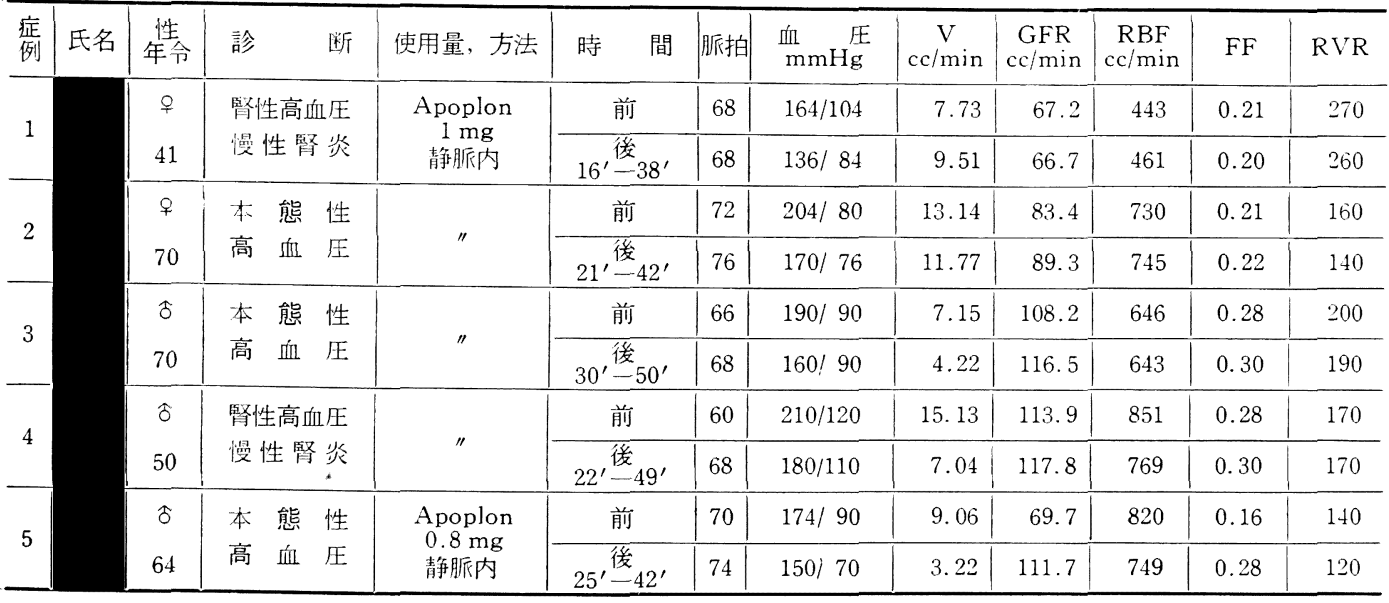

表 7 1-Hydrazinophthalazine (Apresoline) 静注前後の腎機能所見

\begin{tabular}{|c|c|c|c|c|c|c|c|c|c|c|c|c|c|c|c|c|c|}
\hline $\begin{array}{l}\text { 症 } \\
\text { 例 }\end{array}$ & 氏名 & $\begin{array}{l}\text { 性 } \\
\text { 年 } \\
\text { 令 }\end{array}$ & 診 断 & $\begin{array}{l}\text { 使用量, } \\
\text { 方法 }\end{array}$ & 時 間 & \begin{tabular}{|} 
脈 \\
拍
\end{tabular} & $\underset{\mathrm{mmHg}}{\text { 血 }}$ & $\begin{array}{c}\mathrm{V} \\
\mathrm{cc} / \mathrm{min}\end{array}$ & $\begin{array}{c}\text { GFR } \\
\mathrm{cc} / \mathrm{min}\end{array}$ & $\begin{array}{c}\mathrm{RBF} \\
\mathrm{cc} / \mathrm{min}\end{array}$ & $\mathrm{FF}$ & RVR & \begin{tabular}{|r|} 
TRR \\
0
\end{tabular} & $\mid \begin{array}{c}\mathrm{C}_{\mathrm{Na}} \\
\mathrm{cc} / \mathrm{min}\end{array}$ & $\begin{array}{c}\mathrm{C}_{\mathrm{K}} \\
\mathrm{cc} / \mathrm{min}\end{array}$ & $\begin{array}{c}\mathrm{R}_{\mathrm{Na}} \\
\mathrm{O}_{0}\end{array}$ & $\begin{array}{l}\mathrm{R}_{\mathrm{K}} \\
\% \\
0\end{array}$ \\
\hline \multirow{2}{*}{1} & \multirow{2}{*}{\multicolumn{2}{|c|}{$\begin{array}{c}\widehat{\delta} \\
67\end{array}$}} & \multirow{2}{*}{\begin{tabular}{|ll} 
本態性 \\
高 \\
血
\end{tabular}} & \multirow{2}{*}{$\begin{array}{c}\text { Apresolin } \\
20 \mathrm{mg} \\
\text { 静脈内 }\end{array}$} & 前 & $|72|$ & $|206 / 100|$ & 10.25 & 85.8 & 554 & $|0.27|$ & 240 & 88 & & & & \\
\hline & & & & & $4^{\prime}$ 後 $^{\text {作 }}$ & $88 \mid$ & 170,80 & 3.16 & 80.2 & 834 & 0.16 & 130 & 96 & & & & \\
\hline \multirow{2}{*}{2} & & 우 & 監性高血压 & \multirow[b]{2}{*}{ " } & 前 & $80 \mid$ & $210 / 140$ & 2.95 & 17.2 & 148 & $|0.20| 1$ & 1100 & 83 & & & & \\
\hline & & 37 & 慢性腎炎 & & $10^{\prime}-30^{\prime}$ & 100 & $166 / 110$ & 3.73 & 21.6 & 227 & 0.17 & 581 & 83 & & & & \\
\hline \multirow{2}{*}{3} & & $\delta$ & 本態性 & \multirow{2}{*}{ " } & 前 & $|64|$ & $|172 / 90|$ & 7.44 & 89.1 & 737 & $|0.20|$ & 150 & 91 & 5.44 & 23.93 & 94 & 74 \\
\hline & & 64 & 高血圧 & & $11^{\prime}$ 後 $-32^{\prime}$ & 76 & $136 / 76$ & 8.91 & 92.7 & 985 & 0.15 & 90 & 88 & 6.64 & 26.44 & 93 & 72 \\
\hline
\end{tabular}


$-68-(1872)$

$20 \mathrm{mmHg}$ で収縮期血圧の下降に大体平行した。眽拍 数には殆んど変化を認めなかつた。2例（症例 4 , 症 例 5) :括いて RBF の減少㑯向がみられ，1例（症 例 5 ）法いて GFR の $60.3 \%$ の増加を又たが，他 は殆んど不変であつた。しかし RVR は, 不変 1 例 (症例 4) を除いて, 全例に軽度の低下を示した。

2) 1-Hydrazinophthalazine

表 7 に示す如く, Apresoline $20 \mathrm{mg}$ 静注により, 3 例共に収縮期血圧 $36 \mathrm{mmHg} \sim 44 \mathrm{mmHg}$ の下降と, 脈拍数の增加がみられた。 RBF は全例増加を示し， RVR は全例著明に低下した。GFRには殆んど影㗽圭 みず，FFは 0.03〜0.11 に及ぶ低下を示した。1例 において $\mathrm{C}_{\mathrm{Na}}, \mathrm{C}_{\mathrm{K}}, \mathrm{R}_{\mathrm{Na}}, \mathrm{R}_{\mathrm{K}}$ を測定したが，変化を みなかつた。

3) Hexamethonium

表 8 に示寸如く $\mathrm{C}_{6}, 25 \mathrm{mg}$ の筋肉内注射により, 全 例に 16〜36 mmHg に及ぶ収縮期血圧の下降を生じた が，脈拍数には影隦はなかつた。 RBFは1例を除い て減少を示し，GFR は增加 1例, 減少 2 例（1例は $40 \%$ に及ぶ著明な減少)，他は不変であつた。 RVRは 3例に扮いて下降を示した。 $\mathrm{C}_{\mathrm{Na}}, \mathrm{C}_{\mathrm{K}}$ は共に減少し た。

4) Chlorothiazide

本都の静注は裴 9 に示す如く，收縮期，拡張期血圧 共に変化を示さず, 脈拍数にも変化はみられなかつ た。 RBF は1例で減少をみた他は, 一定の变化当み ず, GFR については, 25.20\%の減少を示したI例は 20４2分に回復を示し，25000増加を示した他の1例 は,やはり20〜40 分には恢復の傾向を示した。RVR
には殆んど変化はなかつた。

血中 $\mathrm{Na}, \mathrm{K}$ の変化はみられず， $\mathrm{C}_{\mathrm{Na}}, \mathrm{C}_{\mathrm{K}}$ は1例を 除いて増加を示し，20４3分后にも増加傾向を是した 例（症例 1，2，4）があつた。 $\mathrm{R}_{\mathrm{Na}}, \mathrm{R}_{\mathrm{K}}$ には共に減 少傾向を認めた。TRR は 1〜 5\%の減少を示し, 同時 に尿量の著明な增加 $(2.64 \sim 5.84 \mathrm{cc} / \mathrm{min})$ がみられ た。尿中への $\mathrm{Na}, \mathrm{K}$ の排泄も増加した。しかし TRR の減少, 尿量の增加を示さなかつた 1 例（症例 2 ）も あつた。

5) Hydrochlorothiazide

静注用製剤の入手が困難であつたため，2例につき 検索したのみであるが, 表 10 に示す如く, $50 \mathrm{mg}$ の 静注にて血圧は殆んど变化を示さず, 脈拍数も不変で あり，Chlorothiazide とほぼ同栐の成績であつた。 RBF 飞も著明な影響はみられず， RVR も変化がな かつた。GFR は1例に沶いて减少を示したが，22 分 〜42分にて原值への恢復がみられた。

電解質の面では，2例共に $\mathrm{C}_{\mathrm{Na}}, \mathrm{C}_{\mathrm{K}}$ の増加を示し， TRR の娍少とともに尿量の增加を示し， $R_{N a}, R_{K}$ の 減少並びに尿中えの $\mathrm{Na}, \mathrm{K}$ の排泄増加がみられた。 しかし血中 $\mathrm{Na}, \mathrm{K}$ には変動はみられなかつた。

6) Chlorothiazide と Reserpine の併用 その成績は表 11 に示す如く，3例ともに収縮期 压, 拡張期圧の下降去示した。脈拍数には軽度の変動 はむつたが，一定の傾向はみられなかつた。 RBF は 1 例増加, 2 例不変であつたが, その 1 例の增加量は $203 \mathrm{cc} / \mathrm{min}(30.5 \%$ ) であつた。RVR は3 例と子低下 を示した。GFR は殆んど変動を示さなかつた。

$\mathrm{C}_{\mathrm{Na}}, \mathrm{C}_{\mathrm{K}}$ はやはり著明な増加を示し, $\mathrm{R}_{\mathrm{Na}}, \mathrm{R}_{\mathrm{K}}$ は

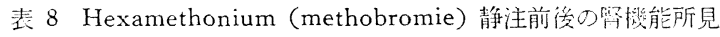

\begin{tabular}{|c|c|c|c|c|c|c|c|c|c|c|c|c|c|c|c|c|c|}
\hline 症 & 氏名 & $\begin{array}{l}\text { 性 } \\
\text { 年 } \\
\text { 令 }\end{array}$ & 診断 & 使用量, 方法 & 時 間 & $\begin{array}{l}\text { 脈 } \\
\text { 指 }\end{array}$ & $\underset{\mathrm{m}}{\stackrel{\text { 血 }}{\text { 压 }} \mathrm{Hg}}$ & $\begin{array}{c}\mathrm{V} \\
\mathrm{cc} / \mathrm{min}\end{array}$ & $\left|\begin{array}{c}\text { GFR } \\
\mathrm{cc} / \mathrm{min}\end{array}\right|$ & $\begin{array}{c}\mathrm{RBF} \\
\mathrm{cc} / \mathrm{min}\end{array}$ & $\mathrm{FF}$ & RVR & $\begin{array}{r}T R R \\
\%\end{array}$ & $\left|\begin{array}{c}\mathrm{C}_{\mathrm{Na}} \\
\mathrm{cc} / \mathrm{min}\end{array}\right|$ & $\left|\begin{array}{c}\mathrm{C}_{\mathrm{K}} \\
\mathrm{cc} / \mathrm{min}\end{array}\right|$ & $\left|\begin{array}{r}\mathrm{R}_{\mathrm{Na}} \\
\%\end{array}\right|$ & $\begin{array}{r}\mathrm{R}_{\mathrm{K}} \\
\% \\
\end{array}$ \\
\hline \multirow{2}{*}{1} & & \multirow{2}{*}{$\begin{array}{l}\hat{\circ} \\
61\end{array}$} & \multirow{2}{*}{$\begin{array}{l}\text { 本態性 } \\
\text { 高血圧 }\end{array}$} & \multirow{2}{*}{$\begin{array}{l}\text { Methobromin } \\
25 \mathrm{mg} \\
\text { 筋肉内注 }\end{array}$} & 前 & $60 \mid$ & $170 / 90$ & 9.24 & 96.7 & 614 & $|0.27|$ & 190 & 92 & 5.03 & $|12.06|$ & 95 & 88 \\
\hline & & & & & $15^{\prime}$ 後 $35^{\prime}$ & 60 & $142 / 74$ & 2.34 & 82.0 & 578 & 0.24 & 160 & 97 & 2.76 & 8.70 & 97 & 90 \\
\hline \multirow[b]{2}{*}{2} & & q & \multirow[b]{2}{*}{ "I } & & 前 & $70 \mid$ & $204 / 110$ & 8.92 & 76.0 & 531 & 0.23 & 260 & 88 & 6.28 & 13.42 & 92 & 83 \\
\hline & & 61 & & & $25^{\prime}$ 後 $45^{\prime}$ & 68 & $168 / 68$ & 3.09 & 80.1 & 497 & 0.29 & 240 & 96 & 3.01 & 7.61 & 97 & 91 \\
\hline \multirow[b]{2}{*}{3} & & $\hat{\delta}$ & \multirow[b]{2}{*}{ " } & \multirow[b]{2}{*}{ " } & 前 & 56 & $|186 / 100|$ & 12.53 & 101.5 & 728 & 0.25 & 170 & 87 & 9.07 & 23.32 & 92 & 78 \\
\hline & & 57 & & & $30^{\prime}-52^{\prime}$ & 58 & $160 / 98$ & 7.10 & 114.2 & 515 & 0.39 & 220 & 93 & 7.59 & 23.15 & 94 & 80 \\
\hline \multirow[b]{2}{*}{4} & & $\delta$ & \multirow[b]{2}{*}{ " } & & 前 & 52 & $170 / 110$ & 12.70 & 113.3 & 913 & $|0.21|$ & 140 & 88 & 2.65 & 17.80 & 98 & 85 \\
\hline & & 52 & & & $22^{\prime}$ 後 $42^{\prime}$ & 56 & $154 / 100$ & 3.63 & 144.0 & 784 & 0.32 & 150 & 90 & 1.43 & 14.51 & 99 & 90 \\
\hline \multirow[t]{2}{*}{5} & & $\delta$ & & \multirow{2}{*}{$\begin{array}{c}\text { Methobromin } \\
35 \mathrm{mg} \\
\text { 筋肉内注 }\end{array}$} & 前 & 64 & 174 & 77 & 104.9 & 697 & $|0.30|$ & 180 & 92 & 63 & 11.16 & 99 & 90 \\
\hline & & 56 & & & $16^{\prime}-37^{\prime}$ & 66 & $146 / 90$ & 2.67 & 2.9 & 10 & 0.17 & 150 & 95 & 1.60 & 6.67 & 98 & 90 \\
\hline
\end{tabular}


表 9 Chlorothiazide (Chlotride) 静注前後の筒機能所見

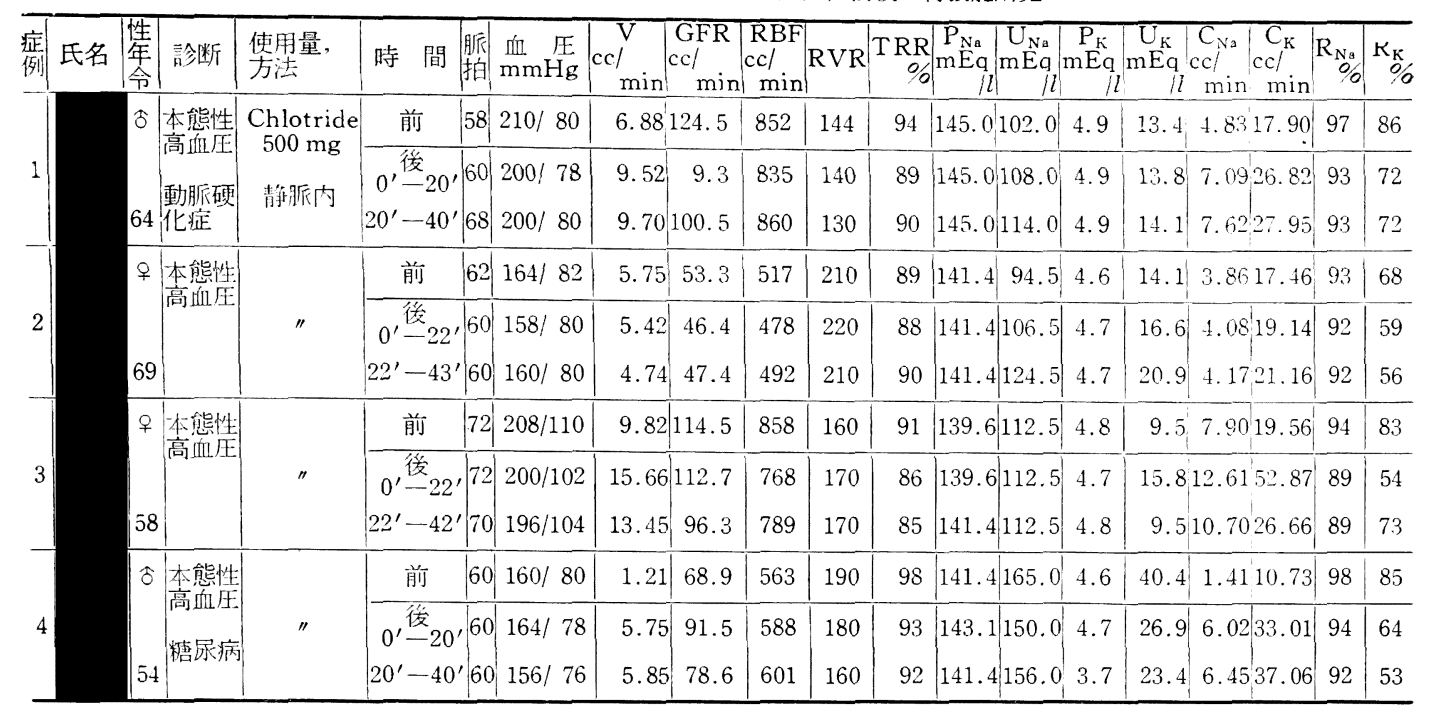

表 11 Hydrochlorothiazide (Dichlotride) 静注前後の腎機能所見

\begin{tabular}{|c|c|c|c|c|c|c|c|c|c|c|c|c|c|c|c|c|c|c|c|}
\hline 姃 氏名 & $\begin{array}{l}\text { 性 } \\
\text { 年 } \\
\text { 令 }\end{array}$ & 析 & 法量, & 時 間 & 脈 & $\underset{\mathrm{m} m \mathrm{mHg}}{\text { 血 }}$ & $\begin{array}{c}\mathrm{V} \\
\mathrm{cc} / \\
\mathrm{min}\end{array}$ & $\left|\begin{array}{|c|}\mathrm{GFR} \\
\mathrm{cc} / \\
\mathrm{min}\end{array}\right|$ & \begin{tabular}{|c|}
$\mathrm{RBF}$ \\
$\mathrm{cc} /$ \\
$\mathrm{min}$
\end{tabular} & $R V R$ & $\begin{array}{r}\text { TRR } \\
\%\end{array}$ & $\mid \begin{array}{r}\mathrm{P}_{\mathrm{Na}} \\
\mathrm{mEq} \\
\quad / l\end{array}$ & $\mid \begin{array}{r}\mathrm{U}_{\mathrm{Na}} \\
\mathrm{mEq} \\
\mid l l\end{array}$ & $\begin{array}{r}\mathrm{P}_{\mathrm{K}} \\
\mathrm{mEq} \\
\\
/ l \\
\end{array}$ & $\begin{array}{r}\mathrm{U}_{\mathrm{K}} \\
\mathrm{mEq} \\
/ l\end{array}$ & $\left|\begin{array}{c}\mathrm{C}_{\mathrm{Na}} \\
\mathrm{cc} / \\
\mathrm{min}\end{array}\right|$ & $\left|\begin{array}{c}\mathrm{C}_{\mathrm{K}} \\
\mathrm{ccl} \\
\mathrm{min}\end{array}\right|$ & $\left|\begin{array}{r}\mathrm{R}_{\mathrm{Na}} \\
0 \%\end{array}\right|$ & $\mathrm{R}_{\mathrm{K}}$ \\
\hline & \multirow[b]{3}{*}{44} & \multirow{3}{*}{ 本態性 } & \multirow{3}{*}{$\begin{array}{l}\text { Dichlot- } \\
\text { ride } \\
50 \mathrm{mg} \\
\text { 青解脈内 }\end{array}$} & 前 & 68 & 90 & 3.02 & 113.6 & 778 & 194 & 97 & 139.6 & 142.5 & 4.7 & 25.0 & 3.08 & 16.13 & 98 & 86 \\
\hline & & & & $0^{\prime}$ 後 $-20^{\prime}$ & & 0 & 11.55 & 118.9 & 721 & 180 & 90 & & 105.0 & 4.7 & 11.9 & & .29 & 93 & 96 \\
\hline & & & & $20^{\prime}-40^{\prime}$ & 68 & $186 / 94$ & 9.34 & $|103.7|$ & 629 & 180 & 90 & 141.4 & 112.5 & 4.8 & 11.9 & & 3.33 & 93 & 78 \\
\hline & \multirow[t]{3}{*}{$\widehat{\delta}$} & \multirow{3}{*}{ 本態性 } & & 前 & 96 & 1 & 3.64 & 130.0 & 987 & 10 & 7 & 139.6 & 124.5 & 4.0 & 15.0 & 3.24 & .65 & 98 & 90 \\
\hline & & & & $0^{\prime}$ 兴 $22^{\prime}$ & $100^{\circ}$ & 1 & 10.36 & 90.8 & 964 & 10 & 88 & 5 & .0 & 4.0 & 7.5 & & & 91 & 79 \\
\hline & & & & $22^{\prime}-42^{\prime}$ & 100 & $150 / 50$ & 8.57 & 133.0 & 980 & 80 & 93 & 140.5 & 129.0 & 3.9 & 8.1 & 7.91 & 17.88 & 95 & 87 \\
\hline
\end{tabular}

表 11 Chlotride, Apoplon 併用静注前後の腎機能所見

\begin{tabular}{|c|c|c|c|c|c|c|c|c|c|c|c|c|c|c|c|c|c|}
\hline 症 & E名 & 性 & 㖣断 & 使用量, & 時 間 & 脤拍 & $\left|\begin{array}{ll}\text { 血 } & \text { 告 } \\
\mathrm{mm} & \mathrm{mg}\end{array}\right|$ & $\begin{array}{c}\mathrm{V} \\
\mathrm{cc} / \mathrm{min}\end{array}$ & $\left|\begin{array}{c}\text { GFR } \\
\mathrm{cc} / \mathrm{min}\end{array}\right|$ & $\left|\begin{array}{c}\mathrm{RBF} \\
\mathrm{cc} / \mathrm{min}\end{array}\right|$ & $\mathrm{FF}$ & RVR & $\begin{array}{r}\mathrm{TRR} \\
\%\end{array}$ & $\begin{array}{c}\mathrm{C}_{\mathrm{Na}} \\
\mathrm{cc} / \mathrm{min}\end{array}$ & $\left|\begin{array}{c}\mathrm{C}_{\mathrm{K}} \\
\mathrm{cc} / \mathrm{min}\end{array}\right|$ & $\left|\begin{array}{r}\mathrm{R}_{\mathrm{Na}} \\
\%\end{array}\right|$ & $\mathrm{R}_{\mathrm{K}}$ \\
\hline \multirow{3}{*}{1} & & \multirow[t]{3}{*}{$\delta$} & \multirow{3}{*}{ 本態性 } & \multirow{3}{*}{$\begin{array}{c}\text { Chlotride } \\
500 \mathrm{mg} \\
\text { Apoplon } \\
1 \mathrm{mg} \\
\text { 青等脤 内 }\end{array}$} & 前 & 74 & $118 / 110$ & & 9 & 666 & 0.29 & 192 & 96 & 4.15 & 26.2 & 96 & 72 \\
\hline & & & & & $23^{\prime}$ 後 $-45^{\prime}$ & 76 & & 10.44 & 102.7 & 869 & 0.25 & 133 & 89 & 7.94 & 34.8 & 94 & 67 \\
\hline & & & & & $45^{\prime}-62^{\prime}$ & 74 & $162 / 96$ & 12.14 & 112.6 & 761 & 0.31 & 155 & 89 & 9.80 & 44.5 & 92 & 61 \\
\hline \multirow{3}{*}{2} & & $\hat{\delta}$ & \multirow{3}{*}{ 本態性 } & \multirow{3}{*}{$\begin{array}{c}\text { Chlotride } \\
500 \mathrm{mg} \\
\text { Apoplon } \\
1 \mathrm{mg} \\
\text { 静 㟲 内 }\end{array}$} & 前 & 68 & 8 & 3.12 & 112.6 & 1153 & 0.20 & 133 & 97 & 3.32 & 16.1 & 97 & 86 \\
\hline & & & & & $24^{\prime}-44^{\prime}$ & 72 & $168 / 112$ & 10.30 & 94.3 & 1130 & 0.17 & 115 & 89 & 6.25 & 26.2 & 94 & 73 \\
\hline & & 42 & & & $44^{\prime}-65^{\prime}$ & 72 & $162 / 110$ & 6 & 94.1 & 830 & 0.22 & 154 & 93 & 5.71 & 19.3 & 94 & 76 \\
\hline \multirow[b]{2}{*}{3} & & 우 & \multirow{2}{*}{\begin{tabular}{|l} 
本態性 \\
高血生
\end{tabular}} & \multirow{2}{*}{$\begin{array}{c}\text { Chlotride } \\
500 \mathrm{mg} \\
\text { Apoplon } \\
1 \mathrm{mg} \\
\text { 静 脈 内 }\end{array}$} & 前 & 70 & $190 / 90$ & 3.62 & 115.0 & 1101 & 0.20 & 115 & 96 & 2.92 & 13.4 & 98 & 89 \\
\hline & & 58 & & & $13^{\prime}-30^{\prime}$ & 68 & $162 / 84$ & 9.35 & 113.5 & 1039 & 0.21 & 105 & 91 & 6.12 & 17.7 & 96 & 85 \\
\hline
\end{tabular}

ともに減少, TRR む 5 8\%の減少を示し, 尿量は増 加し, 尿中への $\mathrm{Na}, \mathrm{K}$ の排泄も増加した。1例に括 いては25〜42 分に扮いてもまだ増加傾向がみられた。

7) Hydrochlorothiazide と Hexamethonium の併 用
3 例につき検索し，その成績を表 12 亿示した。収 縮期血圧は $\mathrm{C}_{6}$ 単独投与群之同様に 22 48 mmHg の 下降を示したが, 脈拍数には僅かに增加がみられ, RVR は堿少を示し, RBF は1例にて増加, GFR は 軽度の増加傾向を示した。 
表 12 Dichlotride 静注, Methobromin 筋注, 併用前後の腎機能所見

\begin{tabular}{|c|c|c|c|c|c|c|c|c|c|c|c|c|c|c|c|c|c|}
\hline 症 & 氏名 & $\begin{array}{l}\text { 性 } \\
\text { 年令 }\end{array}$ & 診断 & 使用量, 方法 & 時 間 & 脈拍 & 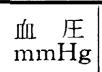 & $\begin{array}{c}\mathrm{V} \\
\mathrm{cc} / \mathrm{min}\end{array}$ & \begin{tabular}{|c|} 
GFR \\
$\mathrm{cc} / \mathrm{min}$
\end{tabular} & $\begin{array}{l}\mathrm{RBF} \\
\mathrm{cc} / \mathrm{min}\end{array}$ & $\mathrm{FF}$ & RVR & \begin{tabular}{|r|} 
TRR \\
$\%$
\end{tabular} & $\begin{array}{c}\mathrm{C}_{\mathrm{Na}} \\
\mathrm{cc} / \mathrm{min}\end{array}$ & \begin{tabular}{c|}
$\mathrm{C}_{\mathrm{K}}$ \\
$\mathrm{cc} / \mathrm{min}$
\end{tabular} & $\begin{array}{r}\mathrm{R}_{\mathrm{Na}} \\
\%\end{array}$ & $\mathrm{R}_{\mathrm{s}}$ \\
\hline & & $\widehat{\delta}$ & \multirow{2}{*}{ 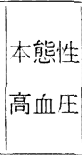 } & \multirow{2}{*}{\begin{tabular}{|l} 
Methobromin \\
$25 \mathrm{mg}$ 笳肉内 \\
15 㣪 \\
Dichlotride \\
$50 \mathrm{mg}$ \\
静脈呙
\end{tabular}} & 前 & 74 & 98 & 1 & 0.0 & 850 & 0.16 & 149 & 98 & 11 & 10.73 & 98 & \\
\hline & & 57 & & & $15^{\prime}$ 後 $-35^{\prime} \mid$ & 76 & $162 ! 84$ & 7.44 & 89.2 & 928 & 0.19 & 117 & 91 & 5.44 & 23.93 & 94 & 74 \\
\hline & & 우 & & \multirow{3}{*}{\begin{tabular}{|l} 
Methobromin \\
$25 \mathrm{mg}$ 筋闪内 \\
$19^{\prime}$ 㣪 \\
Dichlotride \\
$50 \mathrm{mg}$ \\
静㟲内
\end{tabular}} & 前 & 96 & 10 & 1.78 & 9 & 571 & 0.30 & 267 & 98 & 9 & 3.60 & 98 & 84 \\
\hline & & & & & $19^{\prime}-38^{\prime}$ & 100 & $174 / 90$ & 7.50 & 94.1 & 558 & 0.30 & 211 & 92 & 6.63 & 38.74 & 93 & 39 \\
\hline & & 61 & & & $38^{\prime}-53^{\prime}$ & 94 & $162 / 86$ & 7.10 & 96.6 & 578 & 0.27 & 192 & 92 & 5.03 & 12.06 & 95 & 88 \\
\hline & & \multirow[t]{3}{*}{ 우 } & & \multirow{3}{*}{$\begin{array}{c}\text { Methobromin } \\
25 \mathrm{mg} \text { 笳肉内 } \\
25 \text { 徭 } \\
\text { Dichlotride } \\
50 \mathrm{mg} \\
\text { 静脈内 }\end{array}$} & 前 & 71 & $190 / 114$ & 3.57 & 68.1 & 502 & 0.27 & 277 & 95 & 3.28 & 21.23 & 95 & 69 \\
\hline & & & & & $25^{\prime}-42^{\prime}$ & 77 & & 10 & 3 & 498 & 0.31 & 243 & 86 & 7.58 & 3268 & 90 & 58 \\
\hline & & & & & $42^{\prime}-62^{\prime}$ & 80 & $156 / 98$ & 8.92 & 76.0 & 517 & 0.29 & 227 & 88 & 6.28 & 26.74 & 92 & 65 \\
\hline
\end{tabular}

表 13 各種降压戍静 (筋) 注後の腎㙨能所見の变化

\begin{tabular}{|c|c|c|c|c|c|c|c|c|c|c|c|c|c|}
\hline 薬 & 剂 & 名 & 脈拍数 & 血 圧 & $\mathrm{V}$ & $\mathrm{RBF}$ & GFR & RVR & TRR & $\mathrm{C}_{\mathrm{Na}}$ & $C_{K}$ & $\mathrm{R}_{\mathrm{Na}}$ & $\mathrm{R}_{\mathrm{K}}$ \\
\hline & Rs & & $\longrightarrow$ & & 不定 & 不定 & $\ldots \ldots .>$ & & & & & & \\
\hline & $\mathrm{Hy}$ & & & & 不定 & & $\longrightarrow$ & & $\longrightarrow$ & $\longrightarrow$ & $\longrightarrow$ & $\longrightarrow$ & $\longrightarrow$ \\
\hline & $\mathrm{C}_{\theta}$ & & $\longrightarrow$ & & & & 不定 & 不定 & & & & & \\
\hline & $\mathrm{CT}$ & & $\longrightarrow$ & $\longrightarrow$ & & ...... & 不定 & $\longrightarrow$ & & & & & \\
\hline & $\mathrm{HCT}$ & & $\longrightarrow$ & $\longrightarrow$ & & $\longrightarrow$ & $\longrightarrow$ & $\longrightarrow$ & & & & & \\
\hline & $\mathrm{CT}+\mathrm{Rs}$ & & $\longrightarrow$ & & & $\ldots \ldots .$. & $\longrightarrow$ & & & & & & \\
\hline & $\mathrm{HCT}+\mathrm{C}_{6}$ & & & & & -...-> & & & & & & & \\
\hline
\end{tabular}

電解質の面では，やはり $\mathrm{C}_{\mathrm{Na}}, \mathrm{C}_{\mathrm{K}}$ の著增ととも 飞, $\mathrm{R}_{\mathrm{Na}}, \mathrm{R}_{\mathrm{K}}$ いずれも減少を認め, 尿量も増加し,

TRRは6〜900の減少を示した。

これらの変化を $\mathrm{C}_{6}$ 単独投与群と較べるに, RBFの 减少傾向がみられず，GFR はかえつて増加傾向を示 した。又 HCT 単独群と較べると, 血圧下降, RVR の低下などの変化が認められたが，これは $\mathrm{C}_{6}$ を併用 せる以上，当然といつてょかるう。

\section{D. 考案}

降圧剤投与直后の留クリアランスの変動を総括する と, 表 13 の如くになる。

1） $R_{S}$ 投与后の婜クリアランスの変動

$\mathrm{R}_{\mathrm{S}}$ による血圧下降時には， RBF，GFR 飞一定の 変化をみな(18) 20),23) とされて打り，著者の成績もほ ぼこれに一致する。従つてRVR の軽度低下がみられ た。な括興味あることには，投与前の RBF が正常範 囲にあつた例（症例 4，5）に颃いては，投与后 $\mathrm{RBF}$ がやや減少を示したのに対し，投与前 RBF の減少を 示した例（症例 1，2，3）では， $\mathrm{RBF}$ の変動は殆ん どみられなかつた。この点よりみると，投与前 $\mathrm{RBF}$
の減少を示す例の方が，血圧の急激なる下降に対する 反応が小さいように思われる。

2) $\mathrm{Hy}$ 投与後の腎クリアランスの変動

$\mathrm{Hy}$ 降圧時には RBF 増加, 心拍出量增加, 脈拍数 增加を来すとされる24) 26)。著者の症例に㧊いても RBF の増加が名られ，血圧の下降とともに，RVRの 低下が著明であつた。GFR には殆んど変化がなかつ た。特に症例 2 亿执いて，投与前に打ける RBF の高 度減少が，著明に増加し，かつ RVR も著明に低下を 示した事は注目に值する。

3） $\mathrm{C}_{6}$ 投与后の腎クリアランスの変動

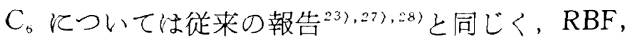
GFR の減少傾向を示した。

4） CT 投与后の筒クリアランスの変動

CT 系薬剤の降圧作用の発現は一般に遅いとされる が，著者が CT の静注（500 mg を5 分）を試みたと ころでも, 血圧の降下は拓こらず,脈拍にも変化はな かつた。腎臓に対する作用としては，RBFには著明 な影晋はなく，GFR は各1例に扣いて多少の増減を みたが，一定の傾向はなく，变化例に扣いて子時間と 
ともに恢復に向う傾向をみた。従つて RVRにも影響 がなかつた。

しかし TRRの低下と共に尿量の增加, $\mathrm{C}_{\mathrm{Na}}, \mathrm{C}_{\mathrm{K}}$ の 增加, $\mathrm{R}_{\mathrm{Na}}, \mathrm{R}_{\mathrm{K}}$ の減少, 尿中 $\mathrm{Na}$ 及び $\mathrm{K}$ の排泄增加 がみられた。Moyer ${ }^{29)}$, Ford ${ }^{30)}$, が犬に括ける静脈内 投与実験飞沏いて, 水, $\mathrm{Na}, \mathrm{K}, \mathrm{Cl}$ の尿中排泄増加を みるも，GFR, RBF には変化を認めないことから， 水及び電解質の細尿管に信ける再吸收阻止が, 本剤の 利尿作用の本態であると主張しているのと一致する。 本剤の降圧作用については Wilkins ${ }^{311}$ 以来多くの 検討が加光られているが，Freis ${ }^{32)}$ は Na 利尿汇もと ずく二次的なものだと述べ,Hollander ${ }^{33)}$ は本剤には 特異的血圧降下作用があるとし，Wilkins ${ }^{31}$ は $\mathrm{Na}$ 利 尿の他に特異的降圧作用があると推測しているが，著 者の実験飞括いて, $500 \mathrm{mg} 1$ 回静注后 2 時間血圧值を 追求せるに, 全く変動をみなかつた点上り,やはり Freis のいう様に，本剤の降圧機序は Na 排泄の增加 にもとずく二次的作用であると考光るのが，妥当かも しれない。しかし，もつと大量を静注すれば速効的な 血圧降下がみられる可能性もあるから，著者の考えは 憶測に過ぎない。

CT 系薬剤の 1 つである HCT については, Moyer 等 ${ }^{34}$ が犬に静脈注射し，血圧の降下と電解質特に塩排 泄量の增加をみている。しかし著者が本態性高血圧 1 例, 腎性高血圧 1 例飞 $50 \mathrm{mg}$ 静注投与を行つたとこ ろでは, 血圧值の変動は注射后 3 時間迄みられなかつ た。

HCT の留瀻に 対する作用としては，RBF は変化 を示さなかつたが，GFR は1例に扮いて $43.2 \%$ の減 少を示した。かつ尿量の著明な增加とともに， $\mathrm{C}_{\mathrm{Na}}$, $\mathrm{C}_{\mathrm{K}}$ の增加, TRR, $\mathrm{R}_{\mathrm{Na}}, \mathrm{R}_{\mathrm{K}}$ の低下をみた。速効的 な降圧作用は $50 \mathrm{mg}$ の静注飞招いては全くみられ ず，やはり $\mathrm{Na}$ 排泄増加による二次的な降圧効果と なす考党を支持出来る所見であつた。

5）降圧剤併用投与后の腎クリアランスの変動 高血圧の治療汇際して, 初期軽症の場合を除いて は， 2 洬或いは 3 剤の併用療法が行われているのが現 況である。

よつて著者は $\mathrm{R}_{\mathrm{S}}$ と CT $500 \mathrm{mg}$ を静脈内に併用投 与し，䝳機能に及活寸影饗を調べた。

その成績は収縮期血圧の降下とともに RVR の低下 がみられたが, 脈拍は不変, $\mathrm{RBF}$ 增加 1 例，他はほ 将不変, GFR 柱全例不変, 尿量, $\mathrm{C}_{\mathrm{Na}}, \mathrm{C}_{\mathrm{K}}$ の增加, $\mathrm{TRR}, \mathrm{R}_{\mathrm{Na}}, \mathrm{R}_{\mathrm{K}}$ の低下を示した。 $\mathrm{CT}$ と $\mathrm{R}_{\mathrm{S}}$ それぞ
れの単独投与では各測定值に一定の影䍀を及ないので あるから，両者の併用投与が一定の変化を示さないの は，当然といつて良いかもしれない。ただし，RBF が 30.5\%增加を示した1例があつたが， $\mathrm{R}_{\mathrm{S}}$ もしくは CT の单独投与では, か子る著明な增加はみられない のであるから，注目に值する。

な扔，両者併用汇上り相乗的な降在作用が党られる かを一応期待したが， $\mathrm{R}_{\mathrm{S}}$ 単独使用時とほぼ同程度に すぎなかつた。

$\mathrm{HCT}$ と $\mathrm{C}_{6}$ の併用について注目に值するのは, RBF の減少をみなかつた事である。C，単独投与の際 には全例 RBF の減少がみられた。従つて HCT の併 用は $C_{6}$ の RBF 减少作用を抑制するものということ が出来る。

$\mathrm{Tapia}^{35)}$ 等及び Freis $^{32}$ は $\mathrm{CT}$ 投年后, 節遮断剂 の投与量を節約できることを指摘して㧊り，Harington $^{36)}$ は Mecamylamin の尿中排泄索抑制し，降圧作 用を強めることを認めている。これらの类験はCT 系 薬剤と節遮断剤の併用療法の有用性在示す七のであ り, 著者が観察せる $\mathrm{RBF}$ 減少㧕制作用も气の一根拠 とみなすととが出来る。

しかし著者の実験では，HCT $+\mathrm{C}_{6}$ に上る降圧効果 の相乗作用はやはり見出さ机なかつた，尚 $\mathrm{C}_{\mathrm{Na}}, \mathrm{C}_{\mathrm{K}}$ については， $\mathrm{C}_{6}$ は減少， HCT は増加を生ずるが， 両者併用時に扔いては增加を示した。この事は $\mathrm{Na}$ 排 泄增加を意味するから，高血圧に対し好結果をもたら すものとみなして良からう。

IV 本龍性高血圧症における電解質クリアランス, 特に $\mathrm{Na}, \mathrm{K}$ クリアランスについて

\section{A. 研究目的}

高血圧の治療として食塩制限が最も高く評洒されて いることは聚知の事実であるが，食湓制限の高血圧に 対する作用機序はまだ未解決である。しかるに近年 Chlorothiazide 采楽剈の降圧作用が知られるに至り， その $\mathrm{Na}$ 排泄增加が，血圧降下機序の本態であると見 なす説 ${ }^{32)}$ が注目をひくに至つた。これらの事より考 之, 本態性高血圧症飞招いて水及び電解質代謝の異 常, 特に電解質クリアランスが重大な意義を有するも のと推測せざるを得ない。

著者はこの見地汇立ち, 高边生症例の電解質クリア ランスを検索しようと試み，次の実験を行つた。

\section{B. 対象及び実験方法}

入院及び外来の本態性高血圧患者 22 例（男子17例， 女子 5 例）を対象とした。年令は 31 才上り 70 才であ 
表 14 健常対照における $\mathrm{Na}, \mathrm{K}$ クリアランス諸值

\begin{tabular}{|c|c|c|c|c|c|c|c|c|c|c|c|c|c|}
\hline & $\begin{array}{c}\text { GFR } \\
\mathrm{cc} / \mathrm{min}\end{array}$ & $\begin{array}{l}\mathrm{RBF} \\
\mathrm{cc} / \mathrm{min}\end{array}$ & $\underset{\mathrm{mEq} / l}{\mathrm{P}_{\mathrm{Na}}}$ & $\underset{\mathrm{mEq} / l}{\mathrm{U}_{\mathrm{Na}}}$ & $\mid \begin{array}{c}\mathrm{U}_{\mathrm{Na}} \mathrm{V} \\
\mathrm{mEq} / \\
l \text { min }\end{array}$ & $\underset{\mathrm{m}}{\stackrel{\mathrm{P}_{\mathrm{K}}}{\mathrm{q} / l}}$ & $\underset{\mathrm{mEq} / l}{\mathrm{U}_{\mathrm{K}}}$ & $\begin{array}{r}\mathrm{U}_{\mathrm{K}} \mathrm{V} \\
\mathrm{mE} / l \\
\mathrm{~min}\end{array}$ & $\begin{array}{c}\mathrm{C}_{\mathrm{Na}} \\
\mathrm{cc} / \mathrm{min}\end{array}$ & $\begin{array}{c}\mathrm{C}_{\mathrm{K}} \\
\mathrm{cc} / \mathrm{min}\end{array}$ & $\begin{array}{r}\mathrm{R}_{\mathrm{Na}} \\
\%\end{array}$ & $\mathrm{R}_{\mathrm{K}}$ & TRR \\
\hline \multirow{2}{*}{ 正常者 } & 140.5 & 1,168 & 150.1 & 150.0 & 956.76 & 5.0 & 26.9 & 154.68 & 7.90 & 33.01 & 98 & 93 & 96 \\
\hline & 84.4 & 870 & 139.6 & 60.8 & 364.19 & 4.2 & 5.0 & 35.45 & 2.50 & 8.24 & 94 & 88 & 88 \\
\hline 平均值 & 109.0 & 899 & 143.8 & 98.6 & 721.65 & 4.7 & 11.2 & 81.98 & 4.97 & 16.14 & 96 & 86 & 93 \\
\hline 標集偏庢 & & & \pm 1.2 & \pm 25.9 & \pm 121.04 & \pm 0.1 & \pm 6.0 & \pm 11.79 & \pm 1.75 & \pm 6.57 & \pm 1 & \pm 5 & \pm 2 \\
\hline
\end{tabular}

表 15 本態性高血圧症における $\mathrm{Na}, \mathrm{K}$ クリアランス諸値

\begin{tabular}{|c|c|c|c|c|c|c|c|c|c|c|c|c|c|c|c|c|}
\hline 症 & 氏名 & 年令 & $\begin{array}{l}\text { 血 } \begin{array}{r}\text { 列 } \\
\mathrm{mm} \mathrm{Hg}\end{array}\end{array}$ & $\begin{array}{l}\text { GFR } \\
\mathrm{cc} / \mathrm{min}\end{array}$ & $\begin{array}{c}\mathrm{RBF} \\
\mathrm{cc} / \mathrm{min}\end{array}$ & $\underset{\mathrm{mEq} / l}{\mathrm{P}_{\mathrm{Na}}}$ & $\begin{array}{c}\mathrm{U}_{\mathrm{Na}} \\
\mathrm{mEq} / l\end{array} \mid$ & $\begin{array}{r}\mathrm{U}_{\mathrm{Na}} \mathrm{V} \\
\mathrm{mEq} / \mathrm{l} \\
\mathrm{min}\end{array}$ & $\underset{\mathrm{mEq} / l}{\mathrm{P}_{\mathrm{K}}}$ & $\underset{\mathrm{mEq} / l}{\mathrm{U}_{\mathrm{K}}}$ & \begin{tabular}{|c|}
$\mathrm{U}_{\mathrm{K}} \mathrm{V}$ \\
$\mathrm{mE} \mathrm{q} / \mathrm{l}$ \\
$\mathrm{min}$
\end{tabular} & $\begin{array}{c}\mathrm{C}_{\mathrm{Na}} \\
\mathrm{cc} / \mathrm{min}\end{array}$ & $\mid \begin{array}{c}\mathrm{C}_{\mathrm{K}} \\
\mathrm{cc} / \mathrm{min}\end{array}$ & $\mathrm{R}_{\mathrm{Na}}$ & $\mathrm{R}_{\mathrm{K}}$ & $\begin{array}{r}\text { TRR } \\
\% \\
\end{array}$ \\
\hline 1 & & $\begin{array}{c}\hat{0} \\
41\end{array}$ & $200 / 120$ & 146.7 & 921 & 146.7 & 76.6 & 705.86 & 4.4 & 6.25 & 57.59 & 4.80 & 13.00 & 97 & 92 & 94 \\
\hline 2 & & $\begin{array}{c}\widehat{O} \\
50\end{array}$ & $186 / 110$ & 68.9 & 563 & 141.4 & 165.0 & 199.65 & 4.6 & 40.4 & 48.84 & 1.41 & 10.73 & 98 & 85 & 98 \\
\hline 3 & & $\begin{array}{l}\hat{0} \\
30\end{array}$ & $160 / 90$ & 113.6 & 806 & 139.6 & 142.5 & 430.35 & 4.7 & 25.0 & 75.50 & 3.08 & 16.13 & 98 & 86 & 97 \\
\hline 4 & & $\stackrel{9}{4}$ & $210 / 110$ & 114.5 & 858 & 139.6 & 112.5 & 552.37 & 4.8 & 9.5 & 46.44 & 3.95 & 9.78 & 97 & 92 & 95 \\
\hline 5 & & $\begin{array}{c}\text { 우 } \\
69\end{array}$ & $174 / 82$ & 53.3 & 517 & 141.4 & 94.5 & 543.37 & 4.6 & 14.1 & 80.84 & 3.84 & 17.46 & 93 & 68 & 89 \\
\hline 6 & & $\begin{array}{c}\text { 웅 } \\
68\end{array}$ & $190 / 94$ & 67.2 & 440 & 146.7 & 99.0 & 587.07 & 4.7 & 23.1 & 137.16 & 4.00 & 29.24 & 95 & 71 & 91 \\
\hline 7 & & $\begin{array}{l}\text { 우 } \\
64\end{array}$ & $174 / 86$ & 84.3 & 709 & 146.7 & 77.9 & 424.55 & 4.9 & 15.0 & 81.75 & 3.00 & 16.78 & 97 & 81 & 93 \\
\hline 8 & & $\begin{array}{l}10 \\
60\end{array}$ & $180 / 80$ & 117.5 & 625 & 141.0 & 22.5 & 207.90 & 3.8 & 3.0 & 27.00 & 1.46 & 7.36 & 99 & 94 & 92 \\
\hline 9 & & $\begin{array}{l}\hat{8} \\
60\end{array}$ & $206 / 120$ & 101.2 & 556 & 143.1 & 84.0 & 478.38 & 5.0 & 5.0 & 28.48 & 3.34 & 5.71 & 97 & 95 & 94 \\
\hline 10 & & $\begin{array}{l}\hat{0} \\
54\end{array}$ & $176 / 110$ & 62.9 & 710 & 141.5 & 85.0 & 226.95 & 4.0 & 10.0 & 26.70 & 1.60 & 6.67 & 98 & 90 & 95. \\
\hline 11 & & $\begin{array}{c}\text { 合 } \\
62\end{array}$ & $194 / 110$ & 61.0 & 520 & 141.4 & 109.5 & 199.29 & 4.7 & 25.6 & 46.64 & 1.30 & 0.94 & 98 & 84 & 97 \\
\hline 12 & & $\begin{array}{c}\hat{8} \\
64\end{array}$ & $184 / 90$ & 111.7 & 749 & 140.3 & 156.0 & 502.32 & 4.6 & 10.6 & 34.13 & 3.01 & 16.16 & 97 & 86 & 97 \\
\hline 13 & & $\begin{array}{l}\hat{\delta} \\
51\end{array}$ & {$[66 / 110$} & 144.0 & 913 & 139.0 & 55.0 & 199.65 & 3.6 & 14.4 & 52.27 & 1.43 & 14.41 & 99 & 90 & 97 \\
\hline 14 & & $\begin{array}{l}\hat{8} \\
48\end{array}$ & $180 / 112$ & 82.0 & 614 & 139.6 & 165.0 & 386.10 & 3.6 & 13.3 & 31.00 & 2.76 & 8.70 & 97 & 90 & $9 T$ \\
\hline 15 & & $\begin{array}{c}0 \\
64\end{array}$ & $190 / 92$ & 69.7 & 820 & 141.4 & 87.0 & 394.11 & 4.4 & 11.3 & 60.96 & 2.79 & 11.58 & 96 & 84 & 93. \\
\hline 16 & & $\begin{array}{c}\hat{D} \\
70\end{array}$ & $210 / 110$ & 117.6 & 624 & 141.4 & 22.5 & 207.90 & 3.8 & 3.0 & 27.99 & 1.46 & 7.36 & 99 & 94 & 92 \\
\hline 17 & & $\begin{array}{l}\hat{1} \\
47\end{array}$ & $180 / 100$ & 108.2 & 637 & 145.0 & 82.6 & 590.59 & 4.6 & 5.8 & 41.11 & 4.07 & 8.93 & 97 & 92 & 92 \\
\hline 18 & & $\begin{array}{c}\text { 3 } \\
59\end{array}$ & $220 / 86$ & 115.0 & 794 & 145.0 & 117.0 & 423.54 & 4.5 & 16.7 & 60.45 & 2.92 & 13.40 & 98 & 89 & 96 \\
\hline 19 & & $\begin{array}{c}\hat{8} \\
54\end{array}$ & $170 / 100$ & 112.6 & 810 & 139.9 & 149.2 & 465.50 & 4.6 & 24.0 & 74.88 & 3.32 & 16.10 & 97 & 86 & 97 \\
\hline 20 & & $\begin{array}{c}\hat{8} \\
44\end{array}$ & $168 / 70$ & 68.9 & 563 & 137.8 & 25.0 & 236.00 & 3.8 & 5.0 & 47.20 & 1.71 & 12.42 & 98 & 82 & 86 \\
\hline 21 & & $\begin{array}{c}0 \\
69\end{array}$ & $204 / 80$ & 94.7 & 619 & 143.1 & 35.5 & 215.13 & 3.9 & 7.5 & 45.45 & 1.50 & 11.66 & 99 & 88 & 93 \\
\hline 22 & & $\begin{array}{c}\hat{0} \\
54\end{array}$ & $180 / 90$ & 86.4 & 661 & 145.0 & 34.3 & 350.08 & 4.0 & 4.3 & 43.03 & 2.42 & 11.00 & 98 & 90 & 88 \\
\hline
\end{tabular}

つた。

各症例の筒クリアランス值は GFR $53.3 \mathrm{cc} / \mathrm{min}$ $146.7 \mathrm{cc} / \mathrm{min}$ (平均 $95 \mathrm{cc} / \mathrm{min}$ ), RBF $440 \mathrm{cc} / \mathrm{min} \sim 921$ $\mathrm{cc} / \mathrm{min}$ (平均 $687 \mathrm{cc} / \mathrm{min}$ ) で, 軽度, 中等度障碍例が
多い。

前夜より水分摂取を制限気味とし, 実験当日は絶食 として, 水 $600 \mathrm{cc}$ を与えた。腎クリアランス標準法 に従つて検査を施行し， GFR, RBF を計算により求 
めた。第 III 節で述べたと同様に $\mathrm{Na}, \mathrm{K}$ を測定し,

$\mathrm{C}_{\mathrm{Na}}, \mathrm{C}_{\mathrm{K}}, \mathrm{R}_{\mathrm{Na}}, \mathrm{R}_{\mathrm{K}}$ を算出した。

健常対照として, 既往及び現症に心, 腎, 肝疾㭧の 認められないもの10 例を選び，上記測定を行い，そ の成績を表 14 亿示した。

以下この平均値及び 標準偏差を正常簌囲と見なし て, 本態性高血圧症例と比較した。

\section{C. 検 查成績}

本態性高血圧症に扣ける各成績を一括して表 15 亿 示した。即ち $\mathrm{P}_{\mathrm{Na}}$ は $137.8 \sim 146.7 \mathrm{mEq} / \mathrm{l}$ (平均 $141.8 \mathrm{mEq} / l)$ でほぼ正常範囲に峁つたが， $\mathrm{U}_{\mathrm{Na}}$ は $22.5 \sim 165.0 \mathrm{mEq} / l$ (平均 $90.8 \mathrm{mEq} / l$ ), $\mathrm{U}_{\mathrm{Na}} \mathrm{V}$ は $199.29 \sim 705.86 \mathrm{mEq} / l$ (平均 $387.6 \mathrm{mEq} / l$ ) と低值を 示した。即ち 22 例中, 正常筙囲下限以下のもの19例, $86.3 \%$ であつた。 $\mathrm{C}_{\mathrm{Na}}$ も $1.30 \sim 4.8 \mathrm{cc} / \mathrm{min}$ (平均 $2.68 \mathrm{cc} / \mathrm{min}$ ) と低值を示し, 正常範囲以下のもの 22 例中 15例であり, その内 8 例は $2 \mathrm{cc} / \mathrm{min}$ 以下の值を 示した。 $\mathrm{R}_{\mathrm{Na}}$ は 93 99\% (平均 97\% であり, 22 例 中 11 例が正常範囲以上の值を示し, 他は 1 例を除い て正常範囲にあつた。

Kについては， $\mathrm{P}_{\mathrm{K}} 3.56 \sim 4.98 \mathrm{mEq} / \mathrm{l}$ (平均 4.3 $\mathrm{mEq} / l)$ でやや低めであり, $\mathrm{U}_{\mathrm{K}}$ は $3.03 \sim 40.37 \mathrm{mEq} /$ $l$ (平均 $13.3 \mathrm{mEq} / l$ ) とやや高い值を示したが, $\mathrm{U}_{\mathrm{K}} \mathrm{V}$ は $27.00 \sim 137.16 \mathrm{mEq} / l$ (平均 $50.96 \mathrm{mEq} / l$ ) と正常 笧囲に比してやや低值を示した。 $C_{K}$ は 5.71 29.24 $\mathrm{cc} / \mathrm{min}$ (平均 $12.48 \mathrm{cc} / \mathrm{min}$ ) と広い值を示した。又 $\mathrm{R}_{\mathrm{K}}$ は 68 94\% (平均 $86 \%$ ) で正常例との差はなく, TRR 86 98\% (平均 94\%) であつて正常群と差はな かつた。

\section{D. 考案}

本態性高血圧飞㧤いて, その電解質代謝の異常を追 求した報告 ${ }^{37}$ × 40 《近年多くみられているが, 本症に 打いては Na 排泄異常, 特飞その減少に上る体内保留 傾向が多くの人によつて示摘されている。著者が本態 性高血圧症 22 例について調べた成績では， $\mathrm{P}_{\mathrm{Na}}$ は $137.8 \sim 146.7 \mathrm{mEq} / l$ と正常範囲にあつたが, 尿 $\mathrm{Na}$ 排泄量生平均 $387.6 \mathrm{mEq} / \mathrm{lmin}$ と低下を示し, $\mathrm{C}_{\mathrm{Na}}$ 文 平均 $2.68 \mathrm{cc} / \mathrm{min}$ 之減少し, 22 例中 15 例飞扔いて正 常範囲下限以下の值を示し, その内 $2 \mathrm{cc} / \mathrm{min}$ 以下の 特低值を示するのが，8例あつた。図16 はこれを 示するので, 健常対照との間飞有意の差をもつて $\mathrm{U}_{\mathrm{Na}} \mathrm{V}$ 並びマ $\mathrm{C}_{\mathrm{Na}}$ の低下がみられた。な扔念のため $\mathrm{R}_{\mathrm{Na}}$ についても検討したが, 有意の差はみられなか つた。
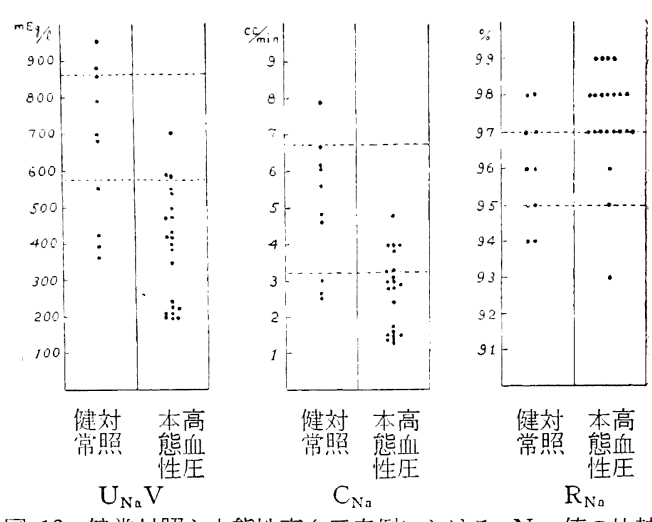

図 16 健常対照と本態性高血圧症例行打方 $\mathrm{Na}$ 值の比較

以上の所見は高血圧症例に扮いて Na の排泄異常の あることを示すもので，近年に㨄ける報告 ${ }^{37) ~}$ と一 致する。

\section{V. 結 論}

1. 本態性高血圧 103 例, 緊性高血圧 18 例飞標準 法により算クリアランス測定を施行し，その成績を各 種臨床所見と対比した。

2. 本態性高血圧に打ける筒クリアランス值を健常 対照に比較するに，37.9\%に扔いて GFR の減少を, 82.5\%に颃いて RBF の減少を認めた。

3. 本態性高血圧飞就いて, 年令の增加とともに, RBF の減少傾向がみられたが, GFR の減少傾向は軽 度であつた。FFは上㫤傾向を示した。

4. 本態性高血圧飞扮いては, 収縮期並びに拡張期 血圧と RBF の間に有意の逆相関がみられたが，GFR との間には相関を認めなかつた。

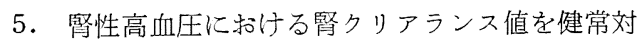
照に比較するに, $77.8 \%$ K GRR 減少を, $88.9 \%$ に RBF 減少を認めた。

6. 腎性高血圧に括いては, GFR は収縮期と拡張 期血圧の双方に, RBF は収縮期血圧のみに有意の逆 相関を示した。

7. 本態性高血圧々腡性高血圧の差について考察す ると，前者ではまず RBF が減少し，GFRは此較的 のちまで保たれるのに対し, 後者では RBF, GFR と もに扮かされると推論された。

8. 本態性・粲性高血圧ともに, $\mathrm{K}-\mathrm{W}$ 度の進行と とも火，RBF 及び GFR の有意の減少をみた。

9. 本態性高血圧飞招ける尿蛋白陽性群は陰性群飞 比し, 有意の差をもつて, RBF, GFR の減少を示し た。

10. 両高血圧ともに, ST・T 異常所見を有するもの 
$-74-(1878)$

は, 有しないものに比し, 有意の差をもつて RBF の 減少を示した。

11. 高血圧患者につき, Reserpine, 1-Hydrazinophthalazine, Hexamethonium 投与直后の腎機能所見 を調ベた。その成績は従来報告されたものと扣招され 一致した。

12. Chlorothiazide 静注直后の腎機能所見を調べる r, 1 分間尿量, $\mathrm{C}_{\mathrm{Na}}, \mathrm{C}_{K}$ は增加, $\mathrm{TRR}, \mathrm{R}_{\mathrm{Na}}, \mathrm{R}_{K}$ は減少，RBF，GFR, RVR は不変乃至不定であつた。 血圧, 脈拍数には変化がなかつた。

13. Hydrochlorothiazide 静注直后の藿機能所見 は, Chlorothiazide に拈けると殆とんど同じであつ た。

14. Chlorothiazide と Reserpine 併用静注直后の 所見は，それぞれの単独投与時と殆んど差がなかつ た。

15. Hydrochlorothiazide ¿ Hexamethonium 併用 注射后の所見は, Hydrochlorothiazide 単独投与時と ほぼ同様であり，Hexamethonium による RBF の減 少は抑制され，RVR の低下を示した。

16. 本態性高血圧 22 例につき $\mathrm{Na}$ 及び $\mathrm{K}$ クリア ランスを調べた。正常対照に比し有意の差をもつて， 尿中 $\mathrm{Na} 1$ 分間排泄量並びに $\mathrm{C}_{\mathrm{Na}}$ の減少がみられた。 $\mathrm{R}_{\mathrm{Na}}$ には有意の差を認めなかつた。

17.このことは, 本態性高血圧の病因に $\mathrm{Na}$ が役割 を演じていることを示浚する。

稿を終るに当り，御指導，御校閲を睗つた木村栄一教授に

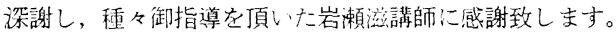

\section{文}

\section{献}

1) Van Slyke D.D. : J. Clin. Invest., 6, 427 (1928)

2) Smith H.W. : Am. J. Phys., 98, 572 (1931)

3）大島研三他：最新医学, 10,1786 (1955)

4）高木秀夫：日循誌，22，605（1958）

5) Chesely C.L. : J. Clin. Invest., 19, 475 (1946)
6) Goldring $W$ et al : Hypertension and Hypertensive Disease N.Y. Common Wealth Fund, (1944)

7）大島研三他：日本臣塸牀，9，535(1951)

8）小林快三他：日循誌，16，149（1952）

9) Corcoran A.C. et al: Ann. Int. Med., 28, 560 (1948)

10）大島研三他：日本臨片， 8, 1069 (1950)

11）上田泰他：日本臨牀, 14, 1646 (1956)

12）三輪清三他：日本臨牀，16，1389（1958）

13）大島研三：綜合臨牀，4，71 (1955)

14）堀井 徹：日内誌，46，150 (1957)

15) Goldring W. et al : J. Clin. Invest., 20, 637 (1941)

16）大島研三他：最新医学, 14, 1316 (1956)

17）上田 泰：実験治療，320 号 270 (1958)

18）村瀨哲郎：福岡医学, 50,2322 (1959)

19) Moyer J.H. et al: Am. J. Med. Sci., 227, 640 (1954)

20) Wilkins R.W. et al : New. Engl. J. Med., 241, 48 (1953)

21) Laragh J.H. et al : J.A.M.A., 166, 145 (1958)

22) Castle C.H. et al : Clin. Res., 6, 107 (1958)

23）高木秀夫：日循誌, 22, 414 (1958)

24) Moyer J.H.et al: J. Clin. Invest., 32, 172 (1953)

25）大島研三：千滈血圧治療文献チ，製薬（1954）

26）相沢豊三：日内誌，42，920 (1954)

27) Freis E.D. et al: J. Clin. Invest., 32, 1285(1953)

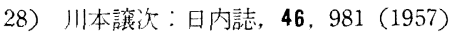

29) Moyer J.H et al : Proc. Soc. exp. Biol., 95, 529 (1957)

30) Ford R.V. et al : Med. Record \& Annals, 11, 376 (1957)

31) Wilkins R.W. : New. Engl. J. Med. 257, 1026 (1957)

32) Freis E.D. et al : J.A.M.A., 166, 137 (1958)

33) Hollander W. et al: The Boston Med. Quartery, 8, 69 (1957)

34) Moyer J H. et al: Am. J. Cardiol., 3, 113(1959)

35) Tapia F.A. et al: Clin. Res. Proc., 5, 293(1957)

36) Harington $M$. et al : Lancet, 7017, 403 (1958)

37）前川棌二郎他：日循誌，23，453（1959）

38）相坂正夫他：内科， 5, 136 (1960)

39) Hollander W.: Clin. Res. Proc, 3, 117 (1955)

40）瀨戸岡進他：最新医学, 11，2535 (1956) 